LBNL-58128

\title{
Tax and Fiscal Policies for Promotion of Industrial Energy Efficiency: A Survey of International Experience
}

\author{
Lynn Price, Christina Galitsky, Jonathan Sinton \\ Environmental Energy Technologies Division \\ Ernest Orlando Lawrence Berkeley National Laboratory \\ Berkeley, CA 94720 USA \\ Ernst Worrell, Wina Graus \\ Ecofys \\ Utrecht, The Netherlands
}

September 2005

This work was supported by the Energy Foundation's China Sustainable Energy Program through the U.S. Department of Energy under Contract No. DE-AC03-76SF0098. 


\section{DISCLAIMER}

This document was prepared as an account of work sponsored by the United States Government. While this document is believed to contain correct information, neither the United States Government nor any agency thereof, nor The Regents of the University of California, nor any of their employees, makes any warranty, express or implied, or assumes any legal responsibility for the accuracy, completeness, or usefulness of any information, apparatus, product, or process disclosed, or represents that its use would not infringe privately owned rights. Reference herein to any specific commercial product, process, or service by its trade name, trademark, manufacturer, or otherwise, does not necessarily constitute or imply its endorsement, recommendation, or favoring by the United States Government or any agency thereof, or The Regents of the University of California. The views and opinions of authors expressed herein do not necessarily state or reflect those of the United States Government or any agency thereof or The Regents of the University of California. 


\title{
Tax and Fiscal Policies for Promotion of Industrial Energy Efficiency: A Survey of International Experience
}

\author{
Lynn Price, Christina Galitsky, Jonathan Sinton, \\ Ernst Worrell, Wina Graus
}

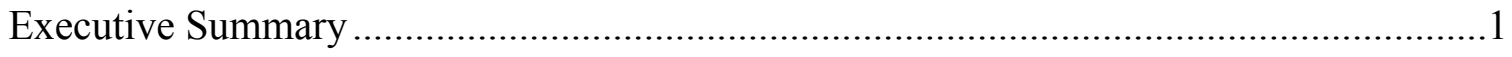

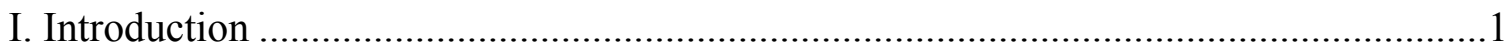

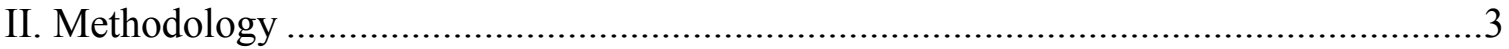

III. Overview of Tax and Fiscal Policies for Promotion of Industrial Energy Efficiency...4

A. Taxes and Fees: Increasing Costs Associated with Energy Use .............................5

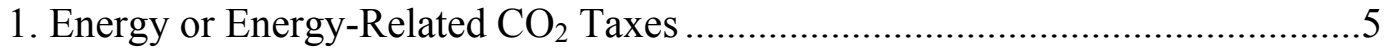

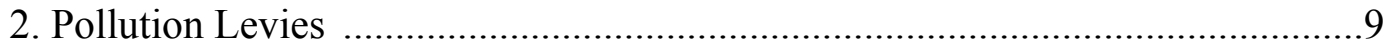

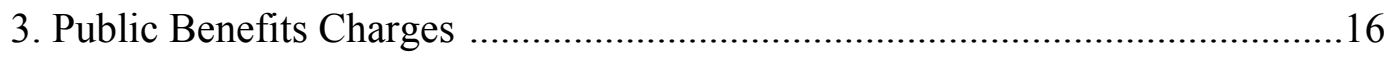

B. Fiscal Policies: Reducing Costs Associated with Increasing Energy Efficiency ...18

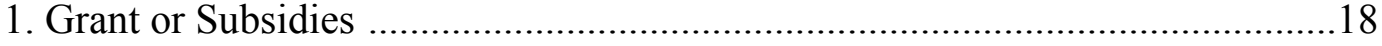

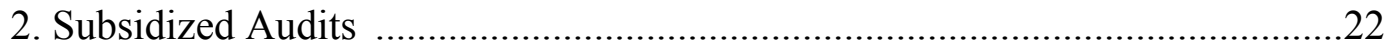

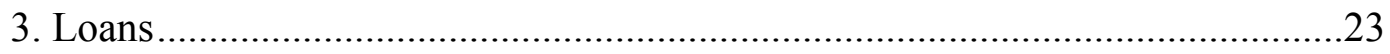

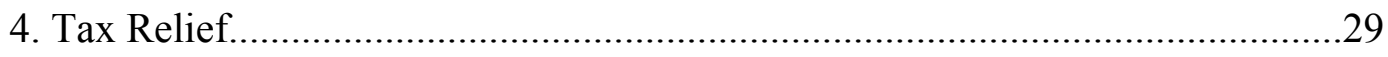

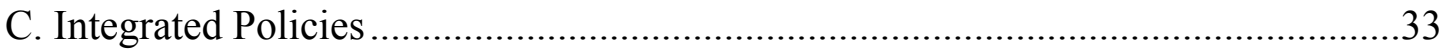

1. Denmark - $\mathrm{CO}_{2}$ Taxes and Voluntary Agreements..........................................33

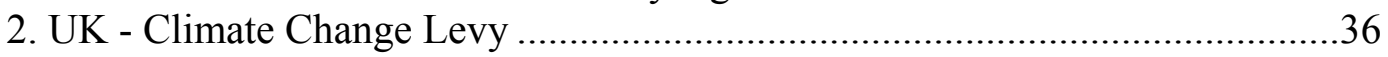

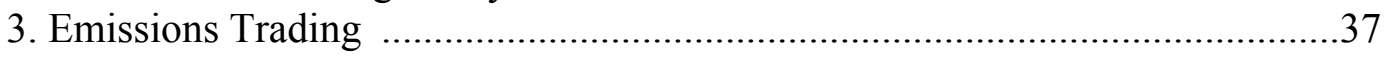

IV. Industrial Energy Efficiency Best International Practices....................................41

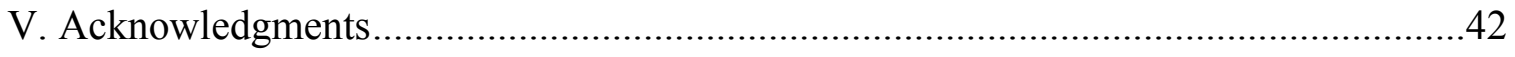

VI. References 43 


\title{
Tax and Fiscal Policies for Promotion of Industrial Energy Efficiency: A Survey of International Experience
}

\author{
Lynn Price, Christina Galitsky, Jonathan Sinton, \\ Ernst Worrell, Wina Graus
}

\section{Executive Summary}

The Energy Foundation's China Sustainable Energy Program (CSEP) has undertaken a major project investigating fiscal and tax policy options for stimulating energy efficiency and renewable energy development in China. This report, which is part of the sectoral sub-project studies on energy efficiency in industry, surveys international experience with tax and fiscal policies directed toward increasing investments in energy efficiency in the industrial sector. The report begins with an overview of tax and fiscal policies, including descriptions and evaluations of programs that use energy or energy-related carbon dioxide $\left(\mathrm{CO}_{2}\right)$ taxes, pollution levies, public benefit charges, grants or subsidies, subsidized audits, loans, tax relief for specific technologies, and tax relief as part of an energy or greenhouse gas (GHG) emission tax or agreement scheme. Following the discussion of these individual policies, the report reviews experience with integrated programs found in two countries as well as with GHG emissions trading programs. The report concludes with a discussion of the "best practices" related to international experience with tax and fiscal policies to encourage investment in energy efficiency in industry.

\section{Introduction}

China's industrial sector accounts for over $70 \%$ of the nation's total primary energy consumption each year. China's industrial sector is heavily dependent on the country's abundant, yet polluting, coal resources. Industrial production locally pollutes the air with emissions of particulates, carbon monoxide, sulfur dioxide, and nitrogen oxides, uses scarce water and oil resources, emits greenhouse gases contributing to the warming global atmosphere, and often produces hazardous and polluting wastes. Fostering innovative approaches to reduce the use of polluting energy resources and to diminish pollution from industrial production that are tailored to China's emerging market-based economy is one of the most important challenges facing the nation today.

China has a history of taking effective actions to limit industrial energy consumption. In 1980, China introduced the energy strategy of "insisting on both resource development and resource conservation with the conservation as the first priority". Numerous energyefficiency polices were adopted that successfully reduced energy use while the economy grew at a rapid pace. Through these programs China was able to decouple energy use from economic growth, allowing the nation to industrialize without draining the national budget to pay exorbitant energy costs that would have occurred without such a concerted effort (Sinton et al., 1998).

During the past 20 years, China experienced an average annual increase of $4 \%$ to $5 \%$ in energy consumption while maintaining average annual economic growth of $8 \%$ to $9 \%$, realizing the goal of meeting increased energy demand half through energy development 
and half through energy saving (Xie Xuren, 2002). One important example of a fiscal incentive program that had a large impact on China's energy efficiency is the energy conservation loan program instituted in 1980. This loan program, which committed $7 \%$ to $8 \%$ of total energy investment to efficiency, primarily in heavy industry, was the largest energy-efficiency investment program ever undertaken by any developing country. The program contributed to a remarkable decline in the energy intensity of China's economy between 1980 and the early 1990s when energy consumption grew at an average rate of $4.8 \%$ per year (compared to $7.5 \%$ in the 1970 s) while GDP grew twice as fast $(9.5 \%$ per year), mainly due to falling industrial sector energy intensity. Of the apparent intensity drop in industry in the $1980 \mathrm{~s}$, about $10 \%$ can be attributed directly to the efficiency investment program (Sinton and Levine, 1994).

These successful programs and policies, however, were implemented during a different era in China - a time when there was nearly complete government control over the nation's major industrial producers. Today China faces a new situation: as it moves toward a market-based socialist economy, government control is weakening and enterprises are privatizing or becoming much more heavily influenced by market pressures. Issues related domestic and international competitiveness are growing in importance. Entry into the World Trade Organization (WTO) introduces new rules and new challenges for China's industries. At the same time, production of industrial materials is growing faster than ever experienced before.

While tremendous energy conservation and environmental protection achievements were realized in the past, there remains a great gulf between the China's current level of energy efficiency and that of the advanced countries of the world. Sustainable development of China will be confronted with many obstacles. On the one hand, due to the large population, China possesses a relative lack of resources, especially oil resources, and the tension between oil supply and oil demand is becoming increasingly obvious. On the other hand, there is a great deal of wasted energy and many examples of low energy efficiency. At present, China's energy consumption per unit of GDP is more than two times higher than world average and energy consumption for production of the main energy-intensive products in China is $40 \%$ higher than international consumption. Thus, sustainable utilization of natural resources has become a strategy for safeguarding the nation's long-term economic development (NDRC, 2004; Price et al., 2003).

Recent power shortages and associated factory closures have highlighted the critical need for energy conservation in China. On March 5, 2005, Premier Wen Jiabao emphasized the importance of increasing energy efficiency in China at the Third Session of the 10th National People's Congress (China Daily, 2005). Focusing on the industrial sector, Premier Wen Jiabao explained:

"Efforts to alleviate the problem of tight supplies of energy and resources needed for economic and social development must start at home by utilizing energy and resources much more efficiently. First, we will resolutely adhere to the policy of simultaneously developing and conserving energy and resources, giving priority to conservation. We will encourage the development and application of new technologies that use less energy and resources, and institute a system requiring the elimination 
of equipment and products that consume excessive quantities of energy and materials. Second, we will promptly draw up standards and targets for reducing energy and resource consumption in every industry, along with policies and measures for meeting the targets. This work will be focused on saving energy, water and materials in key industries."

The Energy Foundation's China Sustainable Energy Program (CSEP) has undertaken a major project investigating fiscal and tax policy options for stimulating energy efficiency and renewable energy development in China. The State Council Development Research Center (DRC) leads this policy study with support of Energy Research Institute (ERI), National Development and Reform Commission (NDRC), the Research Institute of Fiscal Science (RIFS) of the Ministry of Finance (MOF), and more than ten Chinese research institutions. A main report will summarize all signficant findings and policy recommendations of the five cross sector subprojects, including institutional restructuring in the energy sector, fiscal and tax policy, price system reform, investment policy and environmental levies for sustainable energy development. There are also sectoral subproject studies on energy efficiency in buildings, industry, transportation, utilities, and on renewable energy.

This report, which is part of the sectoral sub-project studies on energy efficiency industry, surveys international experience with tax and fiscal policies directed toward increasing investments in energy efficiency in the industrial sector. The report begins with an overview of tax and fiscal policies, including descriptions and evaluations of programs that use energy or energy-related carbon dioxide $\left(\mathrm{CO}_{2}\right)$ taxes, pollution levies, public benefit charges, grants or subsidies, subsidized audits, loans, tax relief for specific technologies, and tax relief as part of an energy or greenhouse gas (GHG) emission tax or agreement scheme. Following the discussion of these individual policies, the report reviews experience with integrated programs found in two countries as well as with GHG emissions trading programs. The report concludes with a discussion of the "best practices" related to international experience with tax and fiscal policies to encourage investment in energy efficiency in industry.

\section{Methodology}

This report represents a collaborative effort between researchers at Lawrence Berkeley National Laboratory (LBNL) in the United States, Ecofys in The Netherlands, the Department for Environment, Food and Rural Development in the UK, the Ministry of Taxation in Denmark, the China Energy Conservation Investment Corporation (CECIC), and the Research Institute of Fiscal Science (RIFS) of the Chinese Ministry of Finance.

LBNL and Ecofys performed the initial literature review, providing program descriptions and evaluations, along with an assessment of international best practices. Preliminary findings were presented to researchers from CECIC and RIFS in a workshop in Beijing in May 2005. Following the workshop, additional research were conducted to answer questions and issues raised at the workshop, as well as to focus on those policies of most interest to CECIC and RIFS. 


\section{Overview of Tax and Fiscal Policies for Promotion of Industrial Energy Efficiency}

Tax and fiscal policies for encouraging investment in energy-efficient industrial equipment and processes operate either through increasing the costs associated with energy use to stimulate energy efficiency or by reducing the costs associated with energy efficiency investments. Various forms of these instruments have been tried in numerous countries over the past two to three decades.

Energy or energy-related carbon dioxide $\left(\mathrm{CO}_{2}\right)$ taxes have been used in a number of countries to provide an incentive to industry to improve the energy management at their facilities through both behavioral changes and investments in energy-efficient equipment. Often these taxes are combined with tax rebates for companies that sign voluntary agreements and reach specified energy efficiency improvements levels. Pollution levies on energy-intensive industries are also a type of tax aimed at reducing emissions and wastes. In addition, public benefit programs (also called system benefit or line charge programs) impose a small energy tax on all users of specific fuels (e.g. electricity) in order to establish public programs and funds that encourage energy efficiency improvement.

Direct and indirect subsidies for distinct groups of energy users (e.g. households, large energy users) are often incorporated into national or regional energy prices. Reducing such subsidies or using energy and $\mathrm{CO}_{2}$ taxes to balance the effect of subsidies provides the energy consumer with a more realistic indication of the actual costs associated with certain forms of energy. In addition, taxes can also be used to more accurately reflect the environmental costs, or "externalities", associated with energy consumption.

Economic incentives that directly reduce the costs associated with increasing energy efficiency include subsidies and loans. Subsidies can either be public funds given directly to the entity investing in energy efficiency or they can be in the form of subsidized services, such as audits. There are also various types of loans with low interest rates for purchase of energy-efficient equipment and loan guarantee schemes. Energy service companies (ESCOs), that provide financing for energy-efficient equipment can also be viewed as providing a loan to the investor. Historically, these economic incentives have been provided by governments and have not sought a financial return. Recently, however, innovative funding mechanisms that use private capital and emphasize a financial return on investments have been implemented in a number of countries (WEC, 2004).

Fiscal incentives indirectly reduce the cost of investments in energy efficiency by reducing taxes paid by consumers. Such incentives can be tax reductions or rebates provided as part of a larger energy or $\mathrm{CO}_{2}$ emissions tax scheme or can be in the form of accelerated depreciation, tax credits, and tax deductions tied to specific energy-efficient technologies.

In addition to these individual measures, integrated policies that combine a variety of financial policies in a national-level energy or GHG emissions mitigation program are 
also found in a number of countries. Such integrated policies are often national-level energy or GHG programs that combine a number of tax and fiscal policies along with other energy efficiency mechanisms such as voluntary agreements. Another example of an integrated policy is emissions trading which involves establishing a desired emissions level (or cap) and allocating permits to industries that can then trade the permits in order to most cost-effectively reach the set emissions cap.

In this study, we begin with a survey of industrial tax and fiscal policies and programs. Table 1 provides a list of tax and fiscal policies for promotion of industrial energy efficiency and indicates which countries around the world have used these policies. For each approach, we discuss international best practice examples of how they have been implemented, including evaluations of the programs where possible.

\section{A. Taxes and Fees: Increasing Costs Associated with Energy Use}

Taxes and fees associated with energy use or with emissions that result from consumption of energy are imposed on users with the goal of creating incentives to reduce wasteful energy consumption practices or of creating public programs and funds for encouraging energy efficiency. Such policies include energy or energy-related $\mathrm{CO}_{2}$ taxes, pollution levies, and public benefit charges.

\section{Energy or Energy-Related $\mathrm{CO}_{2}$ Taxes}

Environmental or "green" taxes such as those imposed on energy use or energy-related $\mathrm{CO}_{2}$ emissions, are considered by economists as theoretically superior to other policy instruments because they internalize the environmental costs associated with energy consumption. The advantages of such taxes are that they aim to reduce demand for the product taxed, they raise revenues, and they reduce pollution and related detrimental health and labor productivity impacts (Royal Society, 2002). Environmental taxes can also bring a "double dividend" through tax shifting where income or labor-related taxes are reduced, creating additional jobs while protecting the environment. The disadvantages are that taxes can have undesirable effects such as disproportional impact on certain sectors of society (e.g. poor households) or on the competitiveness of industrial sectors (Scrimgeour et al., 2005). Controlling and sanctioning related to taxes can be expensive for governments (Johannsen, 2002). Taxes can also result in strong opposition (Royal Society, 2002) and their enactment can become mired in political debate (Johannsen, 2002). While higher prices of energy, either through energy taxes or through carbon taxes, are believed to encourage greater energy efficiency over the long term, a study of small and medium industrial firms in the United States has found that, in the short term, policies to reduce the up-front costs of efficiency investments, e.g., subsidies and tax relief, are more effective at inducing efficiency than higher energy prices (Anderson and Newell, 2004). ${ }^{1}$ Evaluations of the effectiveness of carbon taxes, though, show that they generally achieve their objective of reducing emissions (Scrimgeour et al., 2005).

\footnotetext{
${ }^{1}$ This study, in addition to researching the effects of a long-running program of subsidized energy audits sponsored by the U.S. government through Industrial Assessment Centers, also evaluated the impact of
} 
Taxes on energy or energy-related $\mathrm{CO}_{2}$ emissions were first adopted in a number of northern European countries in the early 1990s. Such taxes are now found in Austria, the Czech Republic, Denmark, Estonia, Finland, Germany, Italy, the Netherlands, Norway, Sweden, Switzerland, and the UK. There have also been studies considering the adoption of energy taxes in Japan and New Zealand (Nakata and Lamont, 2001; Pershing, 2000; Scrimgeour et al., 2005). A recent evaluation of energy and $\mathrm{CO}_{2}$ emissions taxes provides the following guidance (OECD/IEA, 2003):

"When setting individual tax rates, governments need to ensure that rates are high enough to be effective and provide sufficient incentive for action while ensuring that they are not so high that industries close down or relocate, which could just result in carbon 'leakage' rather than reduction. Governments have approached this issue in various ways. For example, some governments have decided, for competitiveness reasons, to allow industry complete or partial exemptions from carbon or carbon/energy taxes applied elsewhere in the economy."

There are large differences between the taxation levied on different energy products in Europe. In most countries (except e.g. Sweden and Denmark), fossil fuels with higher carbon content have lower implicit carbon taxes than those with lower carbon content. In fact, coal is even still heavily subsidized in countries like Germany and Spain (REC, 2000). Empirical studies evaluating the environmental effectiveness of implemented carbon taxes are rather limited. The lack of appropriate studies can be ascribed to the fact that there are several methodological difficulties and complexities in doing such evaluation studies (REC, 2000). The few evaluation studies demonstrate that carbon taxes are an effective instrument in reducing $\mathrm{CO}_{2}$ emissions.

$\mathrm{A} \mathrm{CO}_{2}$ tax for households and industry was introduced in Denmark in 1993. ${ }^{2}$ At first, industry received rebates and reductions that reduced its tax to $35 \%$ of that paid by households. In response, there was a proposal to raise the taxes on industry which ultimately lead to a compromise in which the taxes were increased but industries could receive a reduced tax rate if they joined voluntary agreements. In 1996, the Danish Parliament adopted new taxes under the Green Tax Package in order to conform to the environmental targets concerning reduction of $\mathrm{CO}_{2}$ and sulfur dioxide $\left(\mathrm{SO}_{2}\right)$ emissions. The tax system consists of three types of taxes on energy - a $\mathrm{CO}_{2}$ tax, a $\mathrm{SO}_{2} \operatorname{tax}$ and an energy tax. Taxation of electricity is calculated on the basis of the fuel used in production. Industry has to divide its energy consumption in three categories; space heating, heavy processes and light processes (OPET Network, 2001). The energy tax imposed to the three categories varies (2002 levels):

- Energy for space heating is $100 \%$ of all three types of taxes

- Energy for light processes is $90 \%$ of the $\mathrm{CO}_{2}$ tax, full $\mathrm{SO}_{2}$ tax and no energy tax.

- Energy for heavy processes is $25 \%$ of the $\mathrm{CO}_{2}$ tax, full $\mathrm{SO}_{2}$ tax and no energy tax.

Energy-intensive industrial firms that sign a voluntary agreement pay a reduced tax rate. An evaluation of the impact of the tax in 1997 showed that the industrial companies

technology costs, energy savings, and firm characteristics on adoption of recommended efficiency measures.

${ }^{2}$ The Danish CO2 tax program is further described in Section III.C. 
would have used 10\% more energy if the tax had not been imposed (Bjørner and Jensen, 2002). In an evaluation carried out in 1999, the government estimated that the Green Tax Package 1995 resulted in a net decrease of the overall tax burden and that $\mathrm{CO}_{2}$ emissions from industry in 2005 would be reduced by $3.8 \%$, corresponding to 2.3 million tonnes (Mt). Half of this is due to the taxes and the rest to the subsidy and voluntary agreement schemes (IEA, 2004a).

In Germany, energy taxes were imposed on specific energy sources as part of a program of ecological tax reform. In 1999, the first taxes were imposed on motor fuel, light heating oil, natural gas, and electricity. Revenues generated from the taxes are recycled into employee pension funds (resulting in reduced requirements for employee and employer contributions as well as a net increase in wages). The tax on motor fuel oil and electricity was increased and a tax on heavy heating oil was introduced in 2000. One analysis found that at the end of 2002, more than 7 million tonnes of $\mathrm{CO}_{2}$ emissions would be avoided and 60,000 new jobs would be created. Another analysis of the impact of these energy taxes found "clear signs of the desired ecological effects" including a decrease in energy consumption and the expectation that $\mathrm{CO}_{2}$ emissions will be reduced by $2-3 \%$ by 2005 . The study also found that the energy tax had a positive effect on the labor market, with 250,000 new jobs created (German Federal Ministry for the Environment, Nature Conservation and Nuclear Safety, 2004; Bach, S., 2001a; Bach, S., 2001b; Lutz and Meyer, 2001).

The Netherlands introduced the Regulerende Energiebelasting (REB, Regulating Energy Tax) in 1996. The tax aims at reducing the environmental impact of energy use by increasing the costs of energy. Five energy carriers are taxed (i.e. fuel oil, gas oil, LPG, natural gas and electricity) (Ministry of Housing, Spatial Planning and Environment, 2004). The tax is mainly directed towards households and small energy consumers, through a progressive tax tariff structure that heavily leans on the "first" amount of electricity consumed (up to $10,000 \mathrm{kWh} /$ year). Larger energy users pay only a small amount of taxes; efforts to reduce their energy consumption were conducted primarily through a voluntary agreement program. The tax is paid through the energy bill and the funds are transferred from the energy company to the government. However, other taxes (e.g. income tax) were reduced to achieve no net impact on the tax base. In fact, this has resulted in a minor change in the tax base towards increasing taxation of resources, rather than labor. Social, educational and non-profit organizations can reclaim up to $50 \%$ of the energy taxes through their tax filing (Bode et al., 1998). An early evaluation, less than 2 years after introduction of the tax, showed that only a small number of the companies understood that the tax was introduced, as it was more or less internalized in the energy costs for the company (Bode et al., 1998). The shift in tax burden was also less known under the surveyed companies. Hence, it was hard to estimate the impact of the energy tax on achieved energy savings, but the evaluation noted that the tax is likely to have an impact, even though it was hard to quantify so soon after the introduction of the tax. A $\mathrm{CO}_{2}$ emission reduction in the order of 1.7-2.7 Mt per year in the year 2000 was expected as a result of the tax as it was originally introduced, amounting to $1.5 \%$ of total $\mathrm{CO}_{2}$ emissions in the Netherlands. $\mathrm{CO}_{2}$ emissions from the groups targeted by the tax were projected to decline by something in the order of $5 \%$. The raise in the tax by $€ 1.54$ 
billion in three years (starting in 1999) is expected to generate a $\mathrm{CO}_{2}$ effect of 3.6-3.8 Mt in the year 2010 and 4.6-5.1 Mt in 2020 (Ministry of Housing, Spatial Planning and Environment, 2004).

In 1991, Norway introduced carbon taxes which apply to about $65 \%$ of all $\mathrm{CO}_{2}$ emissions. The $\mathrm{CO}_{2}$ tax contains exemptions for coal and coke used in production of cement and lightweight expanded clay aggregate (LECA) in the processing industry and has a reduced rate for the paper and pulp industry and the production of fishmeal (ProSus, 2005). A tax on heating oil (mineral oil) is applicable for the paper and pulp industry and the production of fishmeal. The tax on consumption of electricity is applicable for all manufacturing industries and greenhouse industries. Tax rates per ton $\mathrm{CO}_{2}$ in 2005 are 41 $€ /$ tonne for petrol, $24 € /$ tonne for light oil, $21 € /$ tonne for heavy oil and the reduced tax rate is $12 € /$ tonne for pulp and paper industry and $11 € /$ tonne for the fishmeal industry (Ministry of Finance, 2005). The tax on electricity consumption for industry is 4.5 $€ / \mathrm{MWh}$. According to Norway's draft budget for 2004, the current energy taxation system is to be replaced by a new electricity tax system for industry the next year. The possibility for industry to have their electricity tax reduced, or even removed, as a result of entering into energy efficiency agreements is seen as a likely component of a new Norwegian electricity tax (FÖS, 2005).

In 1991, the Swedish Carbon Tax was implemented. Industry users were only required to pay $50 \%$ of the tax due to "competitive reasons." Certain high energy-using industries such as commercial horticulture, mining, manufacturing, and the pulp and paper industry are fully exempted from these taxes. In 2002 the tax rate on $\mathrm{CO}_{2}$ was raised from 58 to 69 $€ /$ tonne and the energy tax on electricity increased by $1.3 € / \mathrm{MWh}$. At the same time taxes on labour were reduced by a compensatory amount. The increase in the tax on $\mathrm{CO}_{2}$ and electricity affect only consumers. The reductions in $\mathrm{CO}_{2}$ tax that apply to the industries have been adjusted from $50 \%$ to $70 \%$. This adjustment largely offsets the higher $\mathrm{CO}_{2}$ tax and keeps the overall tax position of these sectors unchanged (IEA, 2004b). Since the implementation of the carbon tax, carbon emissions in Sweden have been reduced. Between the years 1987 and 1994 carbon emissions decreased 6 to 8 Mts, a 13\% decrease in emission levels (Ekins, 1996). An evaluation study of the Swedish $\mathrm{CO}_{2}$ tax carried out by the Swedish Environmental Protection Agency (SEPA) concludes that the $\mathrm{CO}_{2}$ tax has helped to reduce emissions of $\mathrm{CO}_{2}$ in line with Swedish environmental policy (SEPA, 1997). A disadvantage of the Swedish tax code is that it does not reflect the actual level of carbon emitted from fuels. For example, low emission diesel fuel and high-emission diesel fuel are both taxed at the same level despite causing different levels of environment damage.

The federal law on the reduction of $\mathrm{CO}_{2}$ emissions, adopted by the Swiss government in 1999, entered into force in May 2000. The law commits Switzerland to reduce its $\mathrm{CO}_{2}$ emissions by $10 \%$ in 2010 (compared to 1990 levels), in line with the Kyoto Protocol target. Voluntary agreements between the government and industry on cutting $\mathrm{CO}_{2}$ emissions are given the priority. The $\mathrm{CO}_{2}$ law will only be applied if all the other laws influencing the $\mathrm{CO}_{2}$ emission will not suffice to reach the goals of the Kyoto Protocol 
(Pohl and Gisler, 2004). The maximum rate of the tax is fixed at SFr 210 (US\$ 160) per Mt of $\mathrm{CO}_{2}$ emissions (IEA, 2005).

In the UK, the Climate Change Levy was introduced in $2001 .^{3}$ This is a levy on the sales of electricity, coal, natural gas, and liquefied petroleum gas to the business and public sectors. The Climate Change Levy adds about 15\% to typical energy bills for the business and public sectors, but companies that meet negotiated energy efficiency improvement targets receive an $80 \%$ levy discount. All revenue raised is paid back through a $0.3 \%$ cut in employers' National Insurance Contributions and through additional government support for energy efficiency measures and energy-saving technologies. Renewable energy generation is exempted from the tax. Commercial wind energy projects benefit from the system. Some businesses have already set up wind power production sites themselves to avoid the Climate Change Levy (Ragwitz, 2004). The Climate Change Levy should in principle also stimulate fuel switching to lower carbon content fuels. However, levies are not set in relation to carbon content. For example, levy rates for coal and gas are similar. In terms of $\mathrm{CO}_{2}$ the levy is $7 € /$ tonne $\mathrm{CO}_{2}$ for coal, $13 € /$ tonne $\mathrm{CO}_{2}$ for natural gas and $14 € /$ tonne $\mathrm{CO}_{2}$ for electricity (Smith, 2004). The aim of the Climate Change Levy is to reduce $2 \mathrm{Mt} \mathrm{CO}_{2}$ emissions (Oikonomou and Patel, 2004).

\section{Pollution Levies}

Pollution levies are imposed on violators of pollution emissions standards in a number of countries. While these levies are not directly tied to a facility's energy consumption, they are typically imposed on large energy-consuming facilities and the regulated emissions are often associated with energy use.

In general, levels of penalties for environmental offences have been rising across countries, regardless of the type of regulatory system. Minimum penalties are typically small and maxima can be quite large, giving administrative and judicial authorities wide discretionary powers. In many countries, penalties for violations are based on daily rates that can add up to hundreds of thousands of dollars in a single case, or tens of millions of dollars in some recent settlements in the U.S. Some countries allow unlimited penalties, generally informed by the value of damages or the economic benefit the violator gains by the infraction. These higher penalties are credited with having increased the effectiveness of environmental enforcement and motivating regulatory compliance.

Most systems have become more sophisticated over time in balancing the social and economic benefits of violators' activities against the harm of their offences. Experience in the U.S. has borne this out. Other countries with systems of administrative penalties, notably Germany, have also found them effective. It is in part that record of success that is leading other countries to initiate or expand their systems of civil penalties.

Practices vary among countries, but in general one can usefully distinguish between civil and criminal penalties for violating emissions standards, and between judicial and administrative proceedings. Criminal penalties can be difficult to apply, because they

\footnotetext{
${ }^{3}$ The Climate Change Levy is further described in Section III.C.
} 
require lengthy judicial proceedings to prove criminal intent or negligence on the part of individuals or corporations. Civil penalties tend to be easier to pursue, since it is necessary only to show that a violation of regulations has occurred. Civil penalties have thus come to be more widely used. They can be pursued through administrative actions, which are much less costly than court proceedings, though administrative judgments may still be subject to judicial review. Not all countries have provision for administrative procedures. Some have in place only criminal statutes governing environmental violations. Table 1 provides an overview of penalties for violating environmental statutes in selected countries. Cross-country comparisons of sanctions for environmental violations are very difficult to make due to differences in legal codes and other circumstances, so comparisons must be made with great care (Faure and Heine, 2002).

Typically rates for maximum penalties are set per day in which an emitter is in violation, often with a cap for the maximum fine per administrative action or per criminal case. Administrative and judicial authorities usually adjust fines based on considerations including the seriousness of the offence, the intent of the violator, ability of the violator to pay, and benefit to the community of the violator's activities. In many countries, the guidelines for fines can be exceeded based on the judgment of competent authorities, and negotiated or court-ordered settlements can be many times higher than maximum fines listed in schedules.

The current U.S. system for monitoring emissions from stationary sources, monitoring compliance, and levying fines for noncompliance is the result of many years of experience and interaction among government, regulated industries, and the public (Wooley and Morss, 2002). Penalties are one tool of regulatory enforcement. Regulatory enforcement (including civil, criminal and cleanup enforcement) in turn is just one method that United States Environmental Protection Agency (U.S. EPA) uses to ensure compliance. Other methods include compliance assistance, monitoring, auditing and incentives (U.S. EPA, 2005a).

Penalties for emissions violations in the United States can range from warning notices or small fines issued in field actions, to administrative penalties in the hundreds of thousands of dollars, to legal settlements requiring payments of tens to hundreds of millions of dollars and requirements to install new equipment costing as much as or more than the fines themselves (USEPA/OECA, 2004a). In most years, the majority of penalties are the result of civil actions. In fiscal year (FY) 2004, for instance, U.S. EPA's civil penalties totaled $\$ 149$ million, with administrative penalties averaging over $\$ 12,000$ per penalty order and judicial settlements totaling about $\$ 50$ million and averaging about $\$ 450,000$ per case (Harris, 2004). Criminal fines and restitution, by contrast, totaled $\$ 47$ million.

In the early years (1970s and early 1980s), U.S. EPA had difficulty implementing the provisions of the Clean Air Act (CAA). For instance, enforcement actions required the U.S. EPA to go through expensive and time-consuming judicial proceedings and the amounts of penalties were relatively low. New enforcement provisions in the 1990 CAA Amendments, which were modeled after the Clean Water Act, introduced important 
changes that greatly increased effectiveness. Penalties were increased from $\$ 10,000$ per violation to $\$ 25,000$, and penalties were allowed to be assessed for each day in which an emitter was in violation, allowing imposition of even higher penalties. Later increases in penalties were designed to keep pace with inflation, e.g., the 2004 modifications to penalty policies (U.S.EPA, 2004). The maximum penalty for a single violation under the CAA, for instance, was raised from $\$ 27,500$ to $\$ 32,500$ per day, and the maximum for a single administrative action from $\$ 220,000$ to $\$ 270,000$. Higher amounts can be sought with the approval of the EPA Administrator and the U.S. Attorney General (USEPA/OECA, 2004b).

Under the CAA, U.S. EPA and the courts use a variety of factors in determining the size of penalties (Wooley and Morss, 2002). These include the value of the economic benefit derived from the violation, the seriousness of the violation, ability the violator to pay, the violator's compliance history, and other factors. Detailed guidance has been developed for each regulatory arena for calculation of penalties to provide strong incentives for compliance while maintaining cognizance of the public costs of violations (INECE, 2005).

Settlements can be much larger than the amounts indicated in schedules of maximum penalties. Seven diesel engine manufacturers were collectively penalized over $\$ 1$ billion (including $\$ 185$ million in fines and over $\$ 850$ million in retrofit costs) for installing "cheat chips" that allowed their engines to pass laboratory inspections but to exceed emissions standards in actual operation (Johnson, 1998). Exxon also received fines of about $\$ 1$ billion for damage associated with the 1989 Exxon Valdez oil spill in Alaska. There have been many large corporate fines in recent years (Wooley, 2005). In February 2005 , Illinois Power (Dynergy) was fined $\$ 9$ million for new source review violations at a power plant, and the defendant committed to installing a package of emission controls costing hundreds of millions of dollars. Other examples pertaining to enforcement of the Clean Air Act include (USEPA/OECA, 2005):

- In 2002, EPA recovered, and violators will pay, nearly $\$ 40$ million in civil and administrative CAA penalties. EPA secured commitments of $\$ 33$ million in supplemental environmental projects in 2002.

- Boise Cascade (a major wood products company) paid $\$ 4.35$ million in civil penalties and committed to $\$ 18$ million in emission control expenditures (2002).

- Conoco will spend $\$ 100$ million for pollution control technology and will pay a $\$ 1.5$ million civil penalty combined with about $\$ 5$ million on environmental projects in communities around the company's refineries.

- Murphy Oil refinery operations will pay a $\$ 5.5$ million civil penalty.

In some cases, violators may have their penalties reduced by undertaking supplemental environmental projects (SEPs), which are not legally required but help meet other environmental and community objectives (Wooley and Morss, 2002). Such projects totaled \$48 million in FY 2004, nearly the same amount as criminal fines (Harris, 2004). SEPs can be undertaken in the areas of renewable energy or energy efficiency, such as projects to establish facility energy management systems or to perform comprehensive energy audits (USEPA, 2005b). Unlike SEPs, which directly benefit the communities 
affected by the violation, funds from administrative and criminal fines go into the federal government's general revenues. Fines are not retained by environmental authorities.

The size of penalties is not the only ingredient to effectiveness of enforcement. The 1990 CAA enforcement provisions also increased transparency and public accountability. Stationary source emitters were required to monitor and record their own emissions, and these reports were and are made public. Information was made available to citizen groups, which could monitor emitters' compliance and pressure U.S. EPA to enforce its own regulations. Provisions were made for citizens who successfully brought suit against emitters in violation of standards would have their legal costs paid for by the defendant (emitter).

In addition to fines, US EPA wields other powerful tactics. The U.S. vehicle emissions compliance program has recall requirements that mandate that if a substantial number of properly maintained and used vehicles fail to meet emissions standards during their useful life they must be recalled and repaired by the manufacturer. Failure to abide by this provision is punishable by fines up to $\$ 10,000$ per vehicle. Moreover, if individual vehicles fail to meet standards in use they can be repaired at the expense of the manufacturer under warranty requirements (Walsh, 2005).

Like the U.S., Germany distinguishes between criminal and administrative environmental offences. The latter category refers to offenses that are "ethically neutral" and not punishable by imprisonment (Woods and Macrory, 2003). Under administrative procedures, firms can be fined up to $€ 500,000$ for violations of environmental regulations. Fines can be used to recover economic benefits obtained through violations. The only type of imprisonment associated with administrative fines would be short-term coercive terms to enforce payment of fines.

Criminal fines are assessed based on daily rates. Maximum fines, depending on the statute violated, can range from $€ 5,000$ to $€ 100,000$, or alternatively the yearly income of the violator (Huglo Lepage, 2003). Maximum prison sentences vary widely depending on statute, from several months to 10 years.

Currently, the United Kingdom does not employ administrative penalties for environmental infractions, but their use is under consideration (Woods and Macrory, 2003). The current system is pragmatic and flexible in many respects, but relies on the threat of possible judicial proceedings. Civil sanctions, which are already used in other regulatory arenas in the UK, would add flexibility and responsiveness to the current system.

While criminal fines are increasing, and may range up near £1 million, they are not perceived as having a deterrent effect. In 2002, the average penalty was about $£ 2,100$, compared to the maximum of $£ 20,000$ per instance of violation (Woods and Macrory, 2003). Fines are not assessed based on a daily rate. 
Environmental regulation in Japan relies more on a paternalistic "managerial" style of enforcement, in which civil penalties of the sort used in the United States are not common. Emissions exceedances causing direct harm may lead to fines for compensation, but generally fines tend to be small. Overall, Japan makes limited use of economic instruments for environmental protection compared to other developed countries (OECD, 2002; Ren, 2000). However, pressure of various means has been effective in ensuring compliance and in correcting instances of non-compliance. As a result, Japan has an enviable record of compliance with environmental laws and regulations.

Penalties for violations of environmental regulations vary considerably. Some countries without administrative/civil penalties are presently considering whether to institute them. For most of the countries, penalties are assessed on formulas based on daily rates modified by a variety of factors. The literature is often not clear regarding the relationship between daily rates and maximum fines. In most western European countries, the maximum civil or criminal fines for violating the most important statutes regarding water and air pollution and disposal of hazardous wastes range into the hundreds of thousands of euros, and, in some cases, are unlimited by statute and subject to the discretion of the courts. 
Table 1. Overview of Penalties for Violating Environmental Statutes in Selected Countries

\begin{tabular}{|c|c|c|c|c|c|}
\hline \multirow{2}{*}{ Country } & \multicolumn{2}{|c|}{ Administrative/Civil Penalties } & \multicolumn{3}{|c|}{ Criminal Penalties } \\
\hline & Levels of Fines & Remarks & Levels of Fines & Imprisonment & Remarks \\
\hline Australia & $\begin{array}{l}\text { Maximum A } \$ 550,000 \\
\text { (individual), A } \$ 5.5 \\
\text { million (corporate) }\end{array}$ & $\begin{array}{l}\text { Civil/administrative penalties } \\
\text { under review to clarify } \\
\text { distinction from criminal } \\
\text { penalties }\end{array}$ & & & \\
\hline Austria & Maximum $€ 7$ to $€ 36,400$ & Imprisonment up to 2 months & $\begin{array}{l}€ 2 \text { to } € 327 \text { per day, total } € 4 \text { to } \\
€ 117,720\end{array}$ & $\begin{array}{l}\text { Maximum sentences of } 6 \\
\text { months to } 3 \text { years } \\
\text { imprisonment }\end{array}$ & $\begin{array}{l}\text { Fines adjusted depending on } \\
\text { income of violator; maximum } \\
\text { fine is } 360 \text { times daily rate }\end{array}$ \\
\hline $\begin{array}{l}\text { Czech } \\
\text { Republic }\end{array}$ & & & $€ 65$ to $€ 161,000$ & $\begin{array}{l}\text { Maximum sentences of } 15 \\
\text { years imprisonment }\end{array}$ & $\begin{array}{l}\text { Other sanctions and penalties } \\
\text { may be imposed instead of or } \\
\text { in addition to fines and } \\
\text { imprisonment }\end{array}$ \\
\hline Denmark & & $\begin{array}{l}\text { Civil/administrative penalties } \\
\text { under consideration }\end{array}$ & $\begin{array}{l}\text { DKK1,000-10,000 ( } \$ 180- \\
\$ 1,800) \text {, or } 25 \% \text { of economic } \\
\text { benefit of offence }\end{array}$ & $\begin{array}{l}\text { Maximum sentences up to } \\
4 \text { years imprisonment }\end{array}$ & \\
\hline Finland & & & $\begin{array}{l}\text { Individual: } 1 \text { to } 120 \text { “day fines" } \\
\text { (day fine }=1 / 60^{\text {th }} \text { violators' } \\
\text { monthly income); Corporate: } \\
€ 850 \text { to } € 850,000\end{array}$ & $\begin{array}{l}\text { Minimum } 14 \text { days to } \\
\text { maximum } 6 \text { years } \\
\text { imprisonment }\end{array}$ & $\begin{array}{l}\text { Fines are set at discretion of } \\
\text { court; if sentence includes } \\
\text { imprisonment, economic } \\
\text { benefit of violation can be } \\
\text { confiscated }\end{array}$ \\
\hline France & & & $\begin{array}{l}\text { Maximum } € 1,500 \text { to } € 150,000 \\
\text { (individual), } € 7,500 \text { to } € 750,000 \\
\text { (corporate) }\end{array}$ & $\begin{array}{l}\text { Maximum sentences of } 1 \\
\text { to } 3 \text { years imprisonment }\end{array}$ & $\begin{array}{l}\text { Fines may be doubled for } \\
\text { repeat offences; in some cases } \\
\text { fines may be one to two time } \\
\text { the value of the offence }\end{array}$ \\
\hline Germany & Up to $€ 500,000$ & & $\begin{array}{l}\text { Fines calculated on day rate } \\
\text { system, with maximum fines } \\
\text { ranging from } € 5,000 \text { to } \\
€ 100,000\end{array}$ & $\begin{array}{l}\text { Maximum sentences of } 6 \\
\text { months to } 10 \text { years } \\
\text { imprisonment depending } \\
\text { on statute }\end{array}$ & $\begin{array}{l}\text { In corporate cases, only } \\
\text { managers at risk of } \\
\text { imprisonment }\end{array}$ \\
\hline Greece & $\begin{array}{l}\text { Up to } € 300,000 \text { in cases of } \\
\text { severe damage; } \\
\text { indemnification }\end{array}$ & & & $\begin{array}{l}\text { Maximum sentences of } 3 \\
\text { months to } 10 \text { years }\end{array}$ & \\
\hline Hungary & & & & $\begin{array}{l}\text { Minimum } 1 \text { day to } \\
\text { maximum } 8 \text { years } \\
\text { imprisonment }\end{array}$ & $\begin{array}{l}\text { Alternative penalties not } \\
\text { provided for; longer sentences } \\
\text { possible }\end{array}$ \\
\hline
\end{tabular}


Table 1. Overview of Penalties for Violating Environmental Statutes in Selected Countries (continued)

\begin{tabular}{|c|c|c|c|c|c|}
\hline \multirow{2}{*}{ Country } & \multicolumn{2}{|c|}{ Administrative/Civil Penalties } & \multicolumn{3}{|c|}{ Criminal Penalties } \\
\hline & Levels of Fines & Remarks & Levels of Fines & Imprisonment & Remarks \\
\hline Ireland & Up to $£ 1,000$ & Up to 6 months imprisonment & $\begin{array}{l}\text { Summary offences typically up } \\
\text { to } 1,500 \text { plus } £ 200 \text { per day } \\
\text { after first conviction; maximum } \\
£ 10 \text { million plus } £ 100,000 \text { for } \\
\text { continuation after conviction }\end{array}$ & $\begin{array}{l}\text { Maximum sentences of } 6 \\
\text { months to } 10 \text { years }\end{array}$ & $\begin{array}{l}\text { Fines are unlimited under } \\
\text { some statutes }\end{array}$ \\
\hline Portugal & $\begin{array}{l}\text { Fines of } € 37.50 \text { up to } \\
€ 25,000 \text { (individual) and } \\
\text { up to } € 45,000 \text { (corporate) }\end{array}$ & $\begin{array}{l}\text { Rates and maxima vary } \\
\text { according to statute }\end{array}$ & $\begin{array}{l}\text { Fines calculated on day rate } \\
\text { system, with maximum fines } \\
\text { from } 10 \text { to } 600 \text { days, day rate } \\
\text { from } € 1 \text { to } € 500 \text {. }\end{array}$ & $\begin{array}{l}\text { Minimum } 1 \text { month to } \\
\text { maximum } 3 \text { years }\end{array}$ & \\
\hline Slovakia & $\begin{array}{l}\text { Maximum fines up to } \\
€ 125,000\end{array}$ & $\begin{array}{l}\text { Fines may be doubled for repeat } \\
\text { offences, or offenders who fail } \\
\text { to take remedial action }\end{array}$ & $\begin{array}{l}\text { Maximum fines of } € 25 \text { to } \\
€ 7,500\end{array}$ & $\begin{array}{l}\text { Maximum sentences of } 6 \\
\text { months to } 15 \text { years }\end{array}$ & Longer sentences possible \\
\hline Spain & & & $\begin{array}{l}\text { Minimum } € 288 \text { to maximum } \\
€ 21,363\end{array}$ & $\begin{array}{l}\text { Minimum } 6 \text { months to } \\
\text { maximum } 4 \text { years } \\
\text { imprisonment }\end{array}$ & \\
\hline Netherlands & & $\begin{array}{l}\text { Civil/administrative penalties } \\
\text { under consideration }\end{array}$ & $€ 2$ to $€ 450,000$ & $\begin{array}{l}\text { Minimum } 1 \text { day to } \\
\text { maximum } 6 \text { years } \\
\text { imprisonment }\end{array}$ & \\
\hline $\begin{array}{l}\text { United } \\
\text { Kingdom }\end{array}$ & & $\begin{array}{l}\text { Civil/administrative penalties } \\
\text { under consideration }\end{array}$ & $\begin{array}{l}\text { Maximum fines from } £ 5,000 \text { to } \\
£ 20,000 \text {; fines unlimited on } \\
\text { indictment }\end{array}$ & $\begin{array}{l}\text { Maximum sentences } \\
\text { typically } 3 \text { to } 6 \text { months; on } \\
\text { indictment up to } 5 \text { years }\end{array}$ & $\begin{array}{l}\text { Separate statutes with similar } \\
\text { penalties apply in England } \\
\text { and Wales, Scotland, and } \\
\text { Northern Ireland }\end{array}$ \\
\hline United States & $\begin{array}{l}\$ 650 \text { to } \$ 1,000 \text { per } \\
\text { violation (day); maximum } \\
\text { penalties } \$ 1,200 \text { to } \\
\$ 1,000,000\end{array}$ & $\begin{array}{l}\text { Varies depending on statute, } \\
\text { e.g., max. penalties for CAA are } \\
\$ 32,500 \text { per violation (day) and } \\
\$ 270,000 \text { per action; can be } \\
\text { mitigated through Supplemental } \\
\text { Environmental Projects }\end{array}$ & $\begin{array}{l}\text { Criminal fines up to } \$ 5,000 \text { to } \\
\$ 50,000 \text { per day (individual) } \\
\text { and up to } \$ 1 \text { million (corporate) }\end{array}$ & $\begin{array}{l}\text { Misdemeanors: up to } 1 \\
\text { year imprisonment; } \\
\text { Felonies: up to } 5 \text { years } \\
\text { imprisonment }\end{array}$ & $\begin{array}{l}\text { Fines and imprisonment terms } \\
\text { vary depending on statute; } \\
\text { fines and prison terms can be } \\
\text { doubled for repeat offence }\end{array}$ \\
\hline
\end{tabular}

Sources: Sinton and Levine, 2005; Faure and Heine, 2002; Huglo Lepage, 2003; Jendrośka Bar \& Partners et al., 2004; INECE, 2005; USEPA, 2004; Woods and Macrory, 2003; Wooley and Morss, 2002. 


\section{Public Benefits Charges}

Restructuring of public utilities in the second half of the 1990s brought about a change in the design and administration of utility-related programs to promote energy efficiency, renewable energy, and assistance to low income-households. Under the previous system, utilities were regulated monopolies, and were mandated to provide funds for such programs. Restructuring was aimed at introducing competition, and, since spending on public benefits programs did not contribute to financial competitiveness, funding on programs began falling. Since these programs were deemed to provide important benefits, schemes whereby a fee imposed on all distributed electricity would fund these programs were developed and implemented in a number of states (Eto et al., 1998) These fees have been variously termed public benefits charges (PBCs), public goods charges, system benefits charges, line charges, and wires charges. Programs supported by PBCs include energy-efficiency programs, assistance to low-income households, promotion of renewable energy sources, and research, development, and demonstration (RD\&D) for improved energy supply and end-use technologies.

Most experience to date with PBCs has been in U.S., where 25 states $^{4}$ currently have energy efficiency programs funded by utility charges, mainly charges per $\mathrm{kWh}$, but also charges embedded in rates or flat fees to customers (Apollo Alliance, 2004; ACEEE, 2004; Kushler et al., 2004). When put on a common basis, charges for efficiency programs in these states range from 0.03 to $3 \mathrm{mills} / \mathrm{kWh}(1 \mathrm{mill}=\mathrm{US} \$ 0.001)$, with a median of $1.1 \mathrm{mills} / \mathrm{kWh}$. Collective spending on efficiency programs financed through public benefits funds in these states was over US\$900 million.

Experience in the U.S. has shown that the periods for which public benefits funds are authorized to operate have lengthened over time (Kushler et al., 2004). This appears to reflect a recognition by the states of the need for and effectiveness of such funds. This trend provides an important element of stability in funding for energy efficiency, which has fluctuated considerably over time in most states. The long-term commitment has not prevented some states that have confronted budget crises from occasionally raiding public benefits funds and diverting them to other uses.

Kushler et al. also found that, whereas states in the past relied mainly on utilities to administer public benefits efficiency programs, the states are increasingly relying on state agencies and nonprofit organizations. No one approach appears to be best in all situations, and all three have been used with some success. In Kushler et al.'s survey, stakeholders generally rated the programs with which they are associated highly, though the evaluations seem to be associated with trends in funding, with increasing funding associated with more-positive stakeholder assessments. When measured in terms of electricity savings, the state programs led to reductions in electricity use equivalent to $0.1 \%$ to $0.8 \%$ of annual power demand, with a mean of $0.4 \%$, and a combined reduction in demand of over 1,000 MW. On a lifecycle basis, the costs of conserved energy from

\footnotetext{
${ }^{4}$ AR, AZ, CA, CT, DE, IL, MA, MD, ME, MI, MT, NH, NJ, NM, NV, NY, OH, OK, OR, PA, RI, TX, VA, VT, and WI (Apollo Alliance, 2004).
} 
the programs ranged from $\$ 0.023$ to $\$ 0.044$ per $\mathrm{kWh}$. The programs also provided additional benefits in terms of reduced emissions of air pollutants from power plants.

Other countries, like the UK, Austrialia, Norway, and Sweden, have found that deregulation has led to underinvestment in energy efficiency, and have devised programs funded through general revenues or through charges on energy use to address this need (Nadel et al., 1997). In the UK, after discovering that deregulation of electricity and gas utilities did not lead consumers to take advantage of efficiency opportunities, the government established the Energy Saving Trust (ETS). Some of the criticisms leveled at the ETS, for instance, that a PBC represents a tax that is unfairly levied and funneled into wasteful bureaucratic programs, have emerged in the discussion of U.S. programs (Switzer, 2002), even as they have come to be implemented more widely.

In most states with system benefits programs, industrial firms participate in programs run with PBC proceeds. In a very few cases, industrial customers have opted out of participation due to perceived disadvantages. New York's Energy and Research Development Authority (NYSERDA) provides a number of energy-efficiency related services to the industrial sector using funding from the state's PBC. These services include a 50\% cost-shared Flex/Tech Technical Assistance Study in which the industrial facility provided a detailed on-site engineering study that results in a priority list of conservation measures, a commercial/industrial performance program in which energy service companies (ESCOs) provide energy savings in the areas of lighting, motors, and space cooling, and a loan fund that provides interest rate reductions on energy efficiency and renewable energy projects that have payback periods of 10 years or less (Perry, 2004).

California has instituted a variety of programs, financed by a Public Goods Charge and administered by utilities, to serve non-residential customers (FEMP, 2005). Of these, five programs apply to industrial customers, including subsidized energy audits, Savings by Design, Standard Performance Contract, the Express Efficiency Program, and the 500 Plus Peak Program. Savings By Design is a statewide program focused on new and renovated buildings and industrial processes that provides design assistance and incentives to owners (up to $\$ 150,000$ per project if performance exceeds state-set standard practice baseline by at least 10\%) and designers if performance exceeds standard practice baseline by at least 15\%). The Standard Performance Contract subsidizes retrofits to existing gas and electric equipment, and covers both equipment listed in a catalogue and custom projects. Incentives for the former are based on standard calculated savings, and for the latter are based on measured savings. The program covers $50 \%$ of project cost up to $\$ 300,000$ per facility, with statewide caps for corporations and government agencies. The Express Efficiency program is for small and medium gas and electric customers that provides incentives up to $\$ 200,000$ per account per fuel per year for listed HVAC, refrigeration, lighting, and gas equipment. Self-generators with utility connections are also eligible, prorated based on their use of utility-supplied energy. The 500 Plus Peak Program is restricted to large electricity customers $(>500 \mathrm{~kW})$ in the Pacific Gas \& Electric territory (northern California). It is similar to Express Efficiency, with a cap on incentives of $\$ 300,000$ per account per year. 


\section{B. Fiscal Policies: Reducing Costs Associated with Increasing Energy Efficiency}

Fiscal policies include grants or subsidies for investments in energy efficiency, subsidized audits, loans (including both public loans and a number of innovative loan funds), tax relief for purchase of energy-efficient equipment, and tax relief as an element of a larger energy or GHG emission tax or negotiated agreement scheme.

\section{Grants and Subsidies}

Beginning in the 1970s, grants or subsidies for investments in energy efficiency were among the first policy measures to be implemented and remain the most widespread fiscal incentives used today. Grants or subsidies are public funds given directly to the party implementing an energy efficiency project. ${ }^{5}$ Those providing the grants or subsidies, generally the public sector, do not seek a direct financial benefit in the form of return on investment. However, the subsidies are generally provided under the assumption that although the subsidy may be uneconomic for the individual consumer, it will financially benefit the sector and/or country as a whole.

Developing countries with higher risk market environments for investments may find that direct public funding in the form of grants or subsidies are a viable option for encouraging investment in energy efficiency. Public funds may also be needed where competition with more traditional investments such as infrastructure expansion receives most of the available financing, where non-asset based energy efficiency projects are perceived to be riskier than asset-based investments, where energy efficiency projects are too small to gain enough attention or where energy prices do not reflect real costs of energy and are too low for energy efficiency project to procure enough financial benefit for individual companies.

Subsidies are given to companies as a fixed amount, as a percentage of investment (generally with a cap), or as a sum proportional to the amount saved (WEC, 2004). They may also be given to equipment producers for development and marketing. Table 2 shows that 28 countries provide some sort of grant or subsidy for industrial energy efficiency projects; most subsidies were found in European countries (WEC, 2004).

Several potential drawbacks exist for grants or subsidies for energy efficiency projects that are not carefully planned and executed. These include possible free-riders (consumers that would have carried out the investment even without the incentive), a lack of knowledge by targeted consumers preventing uptake of the subsidies, and prohibitively high transaction costs or complex and long procedures to process forms that were too onerous for the consumer.

\footnotetext{
5 Grants and subsidies are also given for energy efficiency research and development projects, demonstration projects, and market development and procurement programs in many countries. In this report we consider only grants and subsidies for implementing energy efficiency measures in an industrial plant as fiscal policy measures, though we acknowledge these other programs do exist.
} 
Table 2. Tax and Fiscal Measures for Promoting Energy Efficiency in the Industrial Sector.

\begin{tabular}{|c|c|c|c|c|c|c|c|c|c|c|c|}
\hline \multirow[b]{2}{*}{ Country } & \multicolumn{3}{|c|}{ Taxes or Fees } & \multicolumn{6}{|c|}{ Fiscal Policies } & \multicolumn{2}{|c|}{ Integrated Policy } \\
\hline & $\begin{array}{c}\text { Energy or } \\
\text { CO2 Tax }\end{array}$ & $\begin{array}{c}\text { Pollution } \\
\text { Levy }\end{array}$ & $\begin{array}{c}\text { Line } \\
\text { Charges }\end{array}$ & $\begin{array}{c}\text { Grants } \\
\text { or } \\
\text { Subsidies }\end{array}$ & $\begin{array}{l}\text { Subsidized } \\
\text { Audits }\end{array}$ & $\begin{array}{l}\text { Public } \\
\text { Sector } \\
\text { Loans }\end{array}$ & $\begin{array}{c}\text { Innovative } \\
\text { Funds }\end{array}$ & $\begin{array}{l}\text { Technology } \\
\text { Tax Relief }\end{array}$ & $\begin{array}{l}\text { Program } \\
\text { Tax Relief }\end{array}$ & $\begin{array}{l}\text { Country } \\
\text { Program }\end{array}$ & $\begin{array}{c}\text { Emissions } \\
\text { Trading }\end{array}$ \\
\hline \multicolumn{12}{|l|}{ OECD } \\
\hline Australia & & $\mathrm{A} / \mathrm{C}$ & $\mathrm{X}$ & $\mathrm{X}$ & $\mathrm{X}$ & & $\mathrm{E}$ & EX & & & \\
\hline Austria & $\mathrm{X}$ & $\mathrm{A} / \mathrm{C}, \mathrm{CR}$ & & $X$ & $\mathrm{X}$ & & $\mathrm{E}$ & & & & $\mathrm{X}$ \\
\hline Belgium & & & & & $\mathrm{X}$ & & $\mathrm{E}$ & & & & $\mathrm{X}$ \\
\hline Bulgaria & & & & & & & $\mathrm{E}$ & & & & \\
\hline Canada & & & & & $\mathrm{X}$ & & E, RF & $\mathrm{AD}$ & & & $\mathrm{X}$ \\
\hline Cyprus & & & & & & & & & & & $\mathrm{X}$ \\
\hline Czech Republic & $\mathrm{X}$ & CR & & $\mathrm{X}$ & & & $\mathrm{E}$ & & & & $\mathrm{X}$ \\
\hline Denmark & $\mathrm{X}$ & CR & & $\mathrm{X}$ & $\mathrm{X}$ & & & & $\mathrm{X}$ & $\mathrm{X}$ & $\mathrm{X}$ \\
\hline Estonia & $\mathrm{X}$ & & & & & & & & & & $\mathrm{X}$ \\
\hline Finland & $\mathrm{X}$ & $\mathrm{CR}$ & & $\mathrm{X}$ & $\mathrm{X}$ & & $\mathrm{E}$ & & & & $\mathrm{X}$ \\
\hline France & $\mathrm{X}$ & $\mathrm{CR}$ & & $\mathrm{X}$ & $\mathrm{X}$ & & GF, IF & & & & $\mathrm{X}$ \\
\hline Germany & $\mathrm{X}$ & $\mathrm{A} / \mathrm{C}, \mathrm{CR}$ & & $\mathrm{X}$ & $\mathrm{X}$ & $\mathrm{X}$ & $\mathrm{E}, \mathrm{IF}$ & EX, R & $\mathrm{X}$ & & $\mathrm{X}$ \\
\hline Greece & & $\mathrm{A} / \mathrm{C}, \mathrm{CR}$ & & $\mathrm{X}$ & & & & & & & $\mathrm{X}$ \\
\hline Hungary & & CR & & $\mathrm{X}$ & $\mathrm{X}$ & $\mathrm{X}$ & E, GF & & & & $\mathrm{X}$ \\
\hline Ireland & & $\mathrm{A} / \mathrm{C}, \mathrm{CR}$ & & & & & & & & & $\mathrm{X}$ \\
\hline Italy & $\mathrm{X}$ & & & $\mathrm{X}$ & $\mathrm{X}$ & & $\mathrm{E}$ & $\mathrm{R}$ & & & $\mathrm{X}$ \\
\hline Japan & & $\mathrm{X}$ & & $\mathrm{X}$ & $\mathrm{X}$ & & $\mathrm{E}$ & $\mathrm{AD}, \mathrm{R}$ & & & \\
\hline Korea (Rep.) & & & & & $\mathrm{X}$ & $X$ & $\mathrm{E}$ & $\mathrm{R}$ & & & \\
\hline Latvia & & & & $\mathrm{X}$ & & $\mathrm{X}$ & & & & & $\mathrm{X}$ \\
\hline Lithuania & & & & & $\mathrm{X}$ & & $\mathrm{E}$ & & & & $\mathrm{X}$ \\
\hline Luxemburg & & & & & & & & & & & $X$ \\
\hline Malta & & & & & & & & & & & $\mathrm{X}$ \\
\hline Mexico & & & & $\mathrm{X}$ & $\mathrm{X}$ & $\mathrm{X}$ & E, IF & & & & \\
\hline Netherlands & $X$ & $\mathrm{CR}$ & & $X$ & $\mathrm{X}$ & & & $\mathrm{AD}, \mathrm{R}$ & & & $\mathrm{X}$ \\
\hline Norway & $\mathrm{X}$ & & $\mathrm{X}$ & $\mathrm{X}$ & $\mathrm{X}$ & & IF & & & & \\
\hline Poland & & & & $X$ & & $X$ & $\mathrm{E}$ & EX & & & $\mathrm{X}$ \\
\hline Portugal & & $\mathrm{A} / \mathrm{C}, \mathrm{CR}$ & & $\mathrm{X}$ & & & $\mathrm{E}$ & EX & & & $X$ \\
\hline Romania & & & & $X$ & & $\mathrm{X}$ & E, IF & EX & & & \\
\hline Russia & & & & $\mathrm{X}$ & & $\mathrm{X}$ & $E$ & $\mathrm{AD}$ & & & \\
\hline Slovakia & & $\mathrm{A} / \mathrm{C}, \mathrm{CR}$ & & $X$ & $X$ & & & & & & $X$ \\
\hline Slovenia & & & & & $X$ & $X$ & $\mathrm{E}$ & EX & & & $\mathrm{X}$ \\
\hline Spain & & $\mathrm{CR}$ & & $\mathrm{X}$ & & $X$ & $\mathrm{E}$ & & & & $\mathrm{X}$ \\
\hline Sweden & $\mathrm{X}$ & & $\mathrm{X}$ & & $\mathrm{X}$ & & & & $\mathrm{X}$ & & $\mathrm{X}$ \\
\hline Switzerland & & & & & $\mathrm{X}$ & & $\mathrm{E}$ & & $\mathrm{X}$ & & \\
\hline Turkey & & & & & $\mathrm{X}$ & & & $\mathrm{AD}, \mathrm{R}$ & & & \\
\hline UK & $\mathrm{X}$ & $\mathrm{CR}$ & & $\mathrm{X}$ & $\mathrm{X}$ & $\mathrm{X}$ & E, VC & $\mathrm{R}$ & $\mathrm{X}$ & $\mathrm{X}$ & $\mathrm{X}$ \\
\hline US & & $\mathrm{A} / \mathrm{C}, \mathrm{CR}$ & $X^{*}$ & $\mathrm{X}^{*}$ & $X$ & $X^{*}$ & $\mathrm{E}$ & EX* & & & $X$ \\
\hline
\end{tabular}


Table 2. Tax and Fiscal Measures for Promoting Energy Efficiency in the Industrial Sector (continued).

\begin{tabular}{|c|c|c|c|c|c|c|c|c|c|c|c|}
\hline \multirow[b]{2}{*}{ Country } & \multicolumn{3}{|c|}{ Taxes or Fees } & \multicolumn{6}{|c|}{ Fiscal Policies } & \multicolumn{2}{|c|}{ Integrated Policy } \\
\hline & $\begin{array}{c}\text { Energy } \\
\text { or CO2 } \\
\text { Tax } \\
\end{array}$ & $\begin{array}{c}\text { Pollution } \\
\text { Levy }\end{array}$ & $\begin{array}{c}\text { Line } \\
\text { Charges }\end{array}$ & $\begin{array}{c}\text { Grants } \\
\text { or } \\
\text { Subsidies } \\
\end{array}$ & $\begin{array}{l}\text { Subsidized } \\
\text { Audits }\end{array}$ & $\begin{array}{l}\text { Public } \\
\text { Sector } \\
\text { Loans } \\
\end{array}$ & $\begin{array}{c}\text { Innovative } \\
\text { Funds }\end{array}$ & $\begin{array}{c}\text { Technology } \\
\text { Tax Relief }\end{array}$ & $\begin{array}{c}\text { Program } \\
\text { Tax } \\
\text { Relief }\end{array}$ & $\begin{array}{l}\text { Country } \\
\text { Program }\end{array}$ & $\begin{array}{c}\text { Emissions } \\
\text { Trading }\end{array}$ \\
\hline \multicolumn{12}{|l|}{ Non-OECD } \\
\hline Brazil & & & & & $\mathrm{X}$ & & GF, RF & $\mathrm{R}$ & & & \\
\hline Colombia & & & & & $\mathrm{X}$ & $\mathrm{X}$ & & & & & \\
\hline Costa Rica & & & & & $\mathrm{X}$ & $\mathrm{X}$ & $\mathrm{E}$ & & & & \\
\hline Cote d'Ivoire & & & & & & & $E$ & & & & \\
\hline Egypt & & & & & $\mathrm{X}$ & $\mathrm{X}$ & $E$ & $\mathrm{R}$ & & & \\
\hline Ghana & & & & & & & $\mathrm{E}$ & & & & \\
\hline Indonesia & & & & & $\mathrm{X}$ & & & & & & \\
\hline Iran & & & & $\mathrm{X}^{* *}$ & $\mathrm{X}$ & $\mathrm{X}$ & $E$ & & & & \\
\hline Israel & & & & & & & & EX & & & \\
\hline Jordon & & & & $\mathrm{X}$ & $\mathrm{X}$ & $\mathrm{X}$ & $E$ & $\mathrm{R}$ & & & \\
\hline Kenya & & & & & $\mathrm{X}$ & & & & & & \\
\hline Lebanon & & & & & $\mathrm{X}$ & & $\mathrm{E}$ & & & & \\
\hline \multicolumn{12}{|l|}{ Libya } \\
\hline Malaysia & & & & & $\mathrm{X}$ & $\mathrm{X}$ & $\mathrm{E}$ & $\mathrm{AD}, \mathrm{R}$ & & & \\
\hline \multicolumn{12}{|l|}{ Morocco } \\
\hline Peru & & & & & $\mathrm{X}$ & & & & & & \\
\hline Philippines & & & & & $\mathrm{X}$ & $\mathrm{X}$ & $E$ & $\mathrm{R}$ & & & \\
\hline Singapore & & & & & & & & $\mathrm{AD}$ & & & \\
\hline South Africa & & & & & & & $E$ & & & & \\
\hline $\begin{array}{l}\text { Taiwan (Rep of } \\
\text { China) }\end{array}$ & & & & $\mathrm{X}$ & $\mathrm{X}$ & & $\mathrm{E}$ & $\mathrm{R}$ & & & \\
\hline Tanzania & & & & & $\mathrm{X}$ & $\mathrm{X}$ & & & & & \\
\hline Thailand & & & & $\mathrm{X}$ & $\mathrm{X}$ & $\mathrm{X}$ & $\mathrm{E}, \mathrm{RF}$ & & & & \\
\hline Tunisia & & & & $\mathrm{X}$ & $\mathrm{X}$ & & $\mathrm{E}$ & & & & \\
\hline Vietnam & & & & & $\mathrm{X}$ & & $\mathrm{E}$ & & & & \\
\hline Total: & 11 & 17 & 4 & 28 & 40 & 21 & 39 & 23 & 5 & 2 & 27 \\
\hline
\end{tabular}

Note: $\mathrm{X}=$ program exists in country, $\mathrm{A} / \mathrm{C}=$ administrative/civil penalties, $\mathrm{CR}=$ criminal penalties, $\mathrm{E}=\mathrm{ESCOs}, \mathrm{GF}=\mathrm{guarantee}$ fund, $\mathrm{RE}=$ revolving fund

$\mathrm{VC}=$ venture capital, $\mathrm{AD}=$ accelerated depreciation, $\mathrm{R}=$ reduction, $\mathrm{EX}=$ exemption

* Provided through state programs, not federal programs.

** This subsidy is linked to a loan (essentially providing a 0 interest loan).

Sources: World Energy Council, 2004. Energy Efficiency: A Worldwide Review - Indicators, Policies, Evaluation. London: WEC.

Galitsky, C., Price, L. and Worrell, E., 2004. Energy Efficiency Programs and Policies in the Industrial Sector in Industrialized Countries. LBNL 54068. 
To combat these problems, grants and subsidies are now limited to better target the proper audience (WEC, 2001a). They can be restricted to certain types of investment, such as a selected list of equipment with a long payback time but high efficiency gains (see Section III.B.4), or can be evaluated on the basis of cost-effectiveness. They can also be targeted toward firms that are more energy-intensive, are of a certain target size, or are participating in a voluntary agreement program.

Australia's Greenhouse Gas Abatement Programme (GGAP) targets all sectors of the economy but focuses on large scale emission reduction projects, especially those that exceed 250,000 tonnes of $\mathrm{CO}_{2}$ equivalent emission reductions annually (Greenhouse Gas Abatement Programme, 2005). In the first two application rounds, 15 projects and almost \$145 million were offered, with a goal of 27 million tonnes of greenhouse gas abatement (Kemp and Macfarane, 2003). Norway's Industrial Energy Efficiency Network (IEEN) program also focused on large enterprises and industries with large total emissions or energy usage (greater than $50 \mathrm{GWh}$ /year) (WEC, 2003; MURE II, 2005).

Other subsidy schemes focus more on small or medium sized enterprises, which may not otherwise be able to afford to undertake large energy efficiency projects. The Netherland's BSET Program focused on small or medium sized enterprises, covering up to $25 \%$ of the costs for specific technologies such as heat recovery, heat pumps and absorption cooling (Kræmer and Stjernström, 1997). In 1994, there were approximately 500 applicants, but the program was discontinued and replaced by other programs (such as the Energy Savings through Innovation Program) in 1995. The Scottish Clean Energy Demonstration Scheme (SCEDS) also focuses on small to medium sized businesses (SEEO, 2005). SCEDS funds grants up to 80,000 GBP (\$150,000 2005 US) for development, demonstration, application and replication of energy efficiency measures and renewable technologies in Scotland (SEEO, 2005).

In its subsidy program, Denmark prioritized the distribution of grants and subsidies to energy-intensive industries and companies involved in a voluntary agreement (Danish Energy Agency, 2000). Subsidies, funded from the green tax revenue, were supplied from 1993 to 2001 to a wide range of projects, though most of the subsidies were granted to value added tax (VAT)-registered companies and $80 \%$ were supplied in energy-intensive sectors. Since January 1, 1996, 6,000 to 7,000 companies have received one or more subsidies.

Some programs tie grants to a cost-effectiveness criterion. Thailand's Energy Conservation Program Fund (ECF) is one example. ECF was created in 1995 as a part of the Energy Conservation Promotion Program (ENCON), funded from a tax on petrol (WEC 2003). ECF provide subsidies in both the public and private sectors, covering up to $50 \%$ of the costs for a facility, up to 500,000 Baht (US\$12,000). In order for a facility to meet Thailand's cost effectiveness criteria, Thailand's program requires that each efficiency measure achieve an internal rate of return of above 9\% (WEC, 2004).

Norway's IEEN program provides grants up to $20 \%$ in any sector investing in energy management or energy monitoring. Like Thailand, Norway also tied grants to cost 
effectiveness in its program that ran from 1990-1993, but Norway set a maximum limit on the rate of return as well as a minimum, from 7 to 30\% (MURE II, 2005). From the 487 projects given a grant, a total of $1050 \mathrm{GWh} /$ year was saved with a total investment of 1,200 million NOK ( $\$ 188$ million 2005 US). Only $16.5 \%$ of these costs were IEEN subsidized (198 million NOK or \$31 million 2005 US).

\section{Subsidized Audits}

Energy audits assess the energy efficiency of a facility and provide technical and financial information about measures that can be taken with regard to energy, including reducing energy consumption, fuel switching, and load management. Energy audits, funded by the government or public utilities, can be partially subsidized or provided entirely free of charge to industry, reducing the transaction costs associated with implementation of new energy-efficient technologies. Subsidized audits are usually provided to companies based on size, amount of energy consumed, or number of employees, targeting specific customers (WEC, 2001a).

Many countries have some sort of audit program, and most of these are subsidized (WEC, 2004; Galitsky et al., 2004). As shown in Table 2, 40 countries have audit programs for the industrial sector. Funding usually varies from 40 to $100 \%$ of the cost of the audit (WEC, 2004).

For audits to be successful, it is important that the auditor fully understand the production and operational processes at the audited plant. To this end, some countries provide a directory or network of accredited auditors or consultants to perform the audits, such as Australia's (former) EEAP and Norway's IEEN and Enova (MURE II, 2005; WEC, 2003). The U.S. Office of Industrial Technologies (OIT) BestPractices Program works with the selected facility to identify potential candidates to help with the audits (U.S. DOE OIT, 2005). For large energy consumers with advanced energy efficiency programs, the UK's Carbon Trust works directly with clients to address specific needs (Carbon Trust, 2005a). Thailand, on the other hand, listed inadequate auditors as one of the program's faults (WEC, 2003).

Targeting specific customers can overcome certain obstacles encountered in audit programs around the world, such as simply a lack of knowledge of the program or freeridership. One such targeting method is to provide audits as a benefit for participants in voluntary agreements, such as in Denmark, the Netherlands and Sweden. Other programs, like Canada's Industrial Energy Audit Incentive, limit subsidized audits to companies that participate in voluntary agreements or other energy efficiency programs. Some countries, alternatively, such as in Portugal, Taiwan, Thailand, Costa Rica, Tunisia and Israel, and half of the 27 European countries surveyed by WEC (2004), require mandatory audits, often for large energy consumers.

Evaluations and follow-up surveys are used to document the effectiveness of subsidized audit programs. For example, Australia's Enterprise Energy Audit Programme (EEAP) found over $80 \%$ of the measures recommended were implemented. Savings identified and 
put in place far exceeded program costs: the EEAP found with only $\$ 4$ million in public funding, and another $\$ 3.25$ million industry funds, savings of $\$ 60$ million were achieved. Many suggested measures were implemented in some schemes: $50 \%$ in the U.S., about $66 \%$ in Finland, $75 \%$ in France, and $80 \%$ in New Zealand (WEC, 2004). Measures offered significant energy and monetary savings and investment were recovered in 1.3 to 3 years, depending on the country and sector. In other counties, however, implementation of the measures was not as successful; in Egypt, for example only 10\% of the measures were implemented (WEC, 2004). Success likely depends on the energy prices and the availability of other measures like financial incentives. The UK has a number of assessments available to its industrial customers, targeting organizations with little or no experience up to organizations wanting to assess their energy management programs. Follow-ups via phone calls and action plans help customers implement measures and realize savings (Carbon Trust, 2005a).

Free-ridership is usually not identified in program evaluations, with the exception of the German program, which found $67 \%$ of the subsidized audits would have been done without the program. Germany also found that many firms interviewed after the program did not know about it. Better targeting (of smaller firms) and better information dissemination about the program may decrease free-ridership in the future (Kræmer and Stjernström, 1997).

\section{Loans}

\section{a. Public Loans (Soft Loans)}

Public, or soft loans are loans subsidized by public funding that are offered at interest rates below market interest rates for investments in energy efficiency. Often these loans are combined with innovative funds or partially fund innovative funds (see below). Like grants, the goal of subsidized loans is to promote energy efficiency measures until they achieve market acceptance level and can be funded on their own. According to WEC (2004), public loans are less popular than subsidies in the countries surveyed.

\section{b. Innovative Funds}

Innovative funds that are aimed at increasing the involvement of banks and private capital in energy efficiency investments are also being used in some countries. In an effort to reduce public debt, trends show a movement toward these types of private sector, rather than the public sector, funds (WEC, 2004). By involving the private sector who seeks profits from their loans, these countries hope to develop a self-sustaining market in the long term, while obtaining a good return on investment in the short term. Generally, both private, "innovative" and public, "soft" loans are used in a given scheme; many innovative funds themselves employ partial public funding.

The main goal of an innovative funding scheme is to get the banks involved and introduce them to making profits by employing energy efficiency. Higher risk market environments that exist in developing countries and emerging economies may make it 
more difficult to raise finance from banks that tend to be conservative in investments, and who are not used to the idea of energy efficiency generating cash (WEC, 2004). Developing countries may also face competition with more traditional investments like expansion of industrial plants or power generation. In addition, energy efficiency projects without large capital investments are often perceived as riskier and/or are too small to attract multilateral financial institution lending. Adaptations that handle these barriers in developing countries or transitional economies are discussed below.

Innovative funds include equity participation through ESCOs, guarantee funds, revolving funds, and venture capital. Each of these is discussed separately, below.

\section{Equity Participation through Energy Service Companies (ESCOs)}

Energy Service Companies, or ESCOs, are private companies that provide project identification, engineering, design, installation, ongoing servicing and maintenance, monitoring and verification of savings, and/or financing of energy and energy efficiency projects. As a part of a private fund geared towards energy efficiency, the ESCO's role is to help to acquire and manage projects within the fund. According to WEC (2004), economies in transition can especially benefit from ESCOs if initial funding can be raised or provided, though they have only very recently been developed there.

There are two main types of contracting used by ESCOs, either acting independently or operating within a fund, to manage the risks associated with lending for energy efficiency: shared savings (or energy performance contracting, EPC) and guarantee savings. ${ }^{6}$ In guarantee savings contracting, the ESCO guarantees a certain level of monetary savings due to reductions in energy consumption from implementing an energy efficiency measure. The ESCO is only paid if these savings are met. In the guarantee savings model, the customers secure their own financing with an outside institution to pay for the project. Therefore, in the guarantee savings model, the customer assumes the debt obligation, the outside lender sustains the credit risk, and the ESCO solely assumes the performance risk.

In the shared savings or EPC model, the ESCO not only guarantees savings for the project but also secures the up-front financing. Like the guaranteed savings model, the ESCO warrants the consumer a fixed reduction in energy consumption but with no required up front capital or other expenditures. Funds are either secured by or funded by the ESCO. Similar to guaranteed savings, the contract stipulates that the energy efficiency cost savings will pay for the cost of implementing the measures, and the ESCO is paid from these savings. However, unlike guaranteed savings, the ESCO secures all up front financing as well. In this way, the ESCO assumes both the performance and credit risks.

EPC affords the consumer the opportunity to deal with only one contractor (or ESCO) who defines, finances, implements and follows up on the energy efficiency measure(s), or coordinates these efforts with others (financier, etc.). The ESCO, often a supplier for building techniques, an engineering company or a utility, carries out services for multiple

\footnotetext{
${ }^{6}$ For more information on ESCOs, contracting and risk-sharing by ESCOs see Hopper, et.al., 2005.
} 
clients and carries the risk of performance and operation. A public agency involved can assist in collection of energy data, negotiations with ESCOs and follow-up on the project. Because of the large risks being undertaken solely by the ESCO, successful funds using EPC have highly expert consults for advice and screening of projects.

One of the main challenges of an ESCO-assisted market is developing interest and identifying the actual funding needed in the beginning to support an energy efficiency market and ESCO involvement. Because energy efficiency projects generally begin with no capital and no balance sheet, banks are initially unwilling to get involved (WEC, 2004). Therefore, an ESCO assisted market's fund initially must put up 100\% of the equity for participation in the first few projects, and fully take on the risk of funding a project with no guarantee of refunding. If and when the fund has proven successful, however, banks may begin to lend money to new projects, and the funds can reduce their own participation to $50 \%$ or even $30 \%$. At this point, the market has been established and ESCOs can enter the market, manage the funds and acquire new projects. One concern with ESCO markets is, due to the fact that ESCOs share savings with the project's owner, only the most cost-effective and least risky measures will be undertaken and the overall extent of energy saving measures might be more limited than if the owners operated independently (WEC, 2003).

The Dexia-Fondelec Fund is one example of a Fund which uses ESCOs as a part of the its scheme. Fondelec brings capital to companies in Central and Eastern Europe from a set of international, institutional investors, each contributing at least 1 million Euro (\$1.3 April 2005 US equivalent), for a total of 70 million Euro ( $\$ 90$ million 2005 US equivalent) (WEC, 2004). The fund either supports projects directly or provides funding for ESCOs. The ESCOs then contract with individual companies to provide the capital, project build-out, and technical monitoring for the projects. In Hungary, the DexiaFondelec Fund purchased an engineering firm and turned it into an ESCO for that market - a company already having expertise in the field as well as a firm with already established, good relationships with its customers. The fund is set up to last from 2000 to 2010, with a possible 2 year extension (WEC, 2004). The French Global Environment Fund (FFEM) supports the fund by covering part of the additional cost of the operations in the region where private investments is still challenging. As of 2004, 40 million Euros (\$52 million 2005 US equivalent) has been earmarked for financing nine projects (WEC, 2004) spanning several industries in both national and export markets. Projects must meet the following conditions: favorable policy, regulatory and business environments, a reliable legal framework, a sophisticated banking system, a local high experienced staff and economic stability.

Fondelec has not yet faced significant difficulties and the fund seems successful (WEC 2004). Key to success of this project included an internationally experienced management team who had already worked with the World Bank on development projects and in developing countries (mostly Latin America and some in Eastern Europe) with experience in the utility sector. In addition, local teams are proficient in both financial issues and in English. The size of the projects, focusing on small to medium enterprises, limits competition with strategic investors or development banks (such as the World 
Bank) that typically focus on larger investments, and spreads out the risk associated with any one project. Pre-review of the projects by investors introduces an additional level of involvement and screening not typically associated with this type of fund.

In Berlin, Germany, an ESCO EPC scheme is in place for public buildings, only (WEC, 2004). From 1995 to 2003, 245 public buildings in Berlin were contracted to public investors who guaranteed energy savings of $22.9 \%$ (WEC, 2004). Because of the large risks associated with an ESCO EPC scheme, keys to the success of the program have included no legal barriers, establishment of contracting guidelines, a competitive market, a highly expert, easily reachable consultant for advice, low fluctuation in energy prices and interest rates and the ability to manage a group of investment and running costs into one administration responsible for other administrative energy costs. A similar program has been developed in Austria for the public sector (WEC, 2004). Finland, Greece, Slovenia and other new EU members through the "Clearinghouse for Third Party Financing in Eastern Europe", supported under the SAVE Programme are also introducing similar programs in the public sector (WEC, 2004). We found fewer programs exist in the industrial market sectors.

\section{Guarantee Funds}

Guarantee funds provide a guarantee to the banks granting loans in the medium and long term. Many countries have guarantee funds, but these funds are generally not adequate in guaranteeing financing for energy efficiency projects and most of them have ceilings on the guarantees (WEC, 2004). In these cases, guarantee funds for energy efficiency can be offered in addition to the national guarantee fund. Guarantee funds cover credit risks associated with financing energy efficiency. To maximize their efficiency, a good assessment of the potential benefits is key.

France, Hungary and Brazil have all established guarantee funds for energy efficiency (WEC, 2004). In France, FOGIME was set up in June of 2001 as a guarantee fund for energy efficiency dedicated to small and medium companies (SMEs). The fund was established by ADEME in partnership with the Bank for the Development of SMEs (BDPME) through its subsidiary company SOFARIS, EDF and Charbonnages de France (WEC 2004). BDPME is held mainly by the State and the Caisse des Dêpots et Consignation (CDC) and controls directly or indirectly the majority of the capital of the Credit for SMEs' equipment. BDPME shares the risk of financing by providing loans with a rate much lower than the capital risk market value (WEC, 2003). ADEME provides an additional $30 \%$ guarantee on top of the $40 \%$ provided by the National guarantee Fund to the banks granting loans for energy efficiency projects for SMEs. The maximum guarantee is 750,000 Euros $(\$ 970,000$ April 2005 US equivalent) per company. Since June 2001, about 30 projects have been accepted and 20 loans have been granted for a credit of 5.6 million Euros (WEC, 2004). Of the 30 projects, 10 had already used ADEME grants for energy audits.

In this scheme, the fund manager has no skills in energy efficiency issues which made it difficult to evaluate potential benefits. However, since many of the projects already had energy audits and experience in energy efficiency, they were likely to submit more 
reliable projects. The fact that three parties are involved - the lending bank, the fund manager (SOFARIS) and the technical advisor (ADEME) - makes the whole procedure more arduous.

\section{Revolving Funds}

What distinguishes revolving funds from other types of loans is that the reimbursement of the loans is recycled back into the fund to support new projects. These funds generally require public or national intervention to support them, either through subsidizing interest rates (low or zero) or by subsidizing the principal investment (WEC, 2004). They can be implemented at the local or national levels. The funds can be applied to any sector. Several advantages exist for revolving funds. Public funding is utilized cost-effectively; the only costs to the sponsor can eventually be administrative, which can be paid back through interest. The borrowers can recover their own financing through their own savings due to increased energy efficiency. Revolving funds that invest in the private sector encourage public/private cooperation.

There are many variations in the design of a revolving fund, such as the possibility of using commercial financial institutions, the scope of the fund's objective, whether a broad scope like environmental issues or a more limited scope like energy efficiency, and finally, who does the technical and economic analysis in choosing the projects to finance. Key to success of these types of projects is having a fund manager that is competent both in financing (as in banks) but also in environmental issues as in the Canadian Municipal Green Fund's managers. A World Bank sponsored workshop noted that revolving funds are useful in countries where market-based prices and supporting governmental policy creates a demand for energy efficiency projects (Energy Efficiency Operation Exchange Program, World Bank 2000). They also recommend having a clear objective of the fund, keeping the process simple and transparent, and using third parties like ESCOs wherever possible to market and develop projects for the fund.

Some revolving funds provide zero-interest rate loans to banks. The banks lend at an interest rate that covers transaction costs and a minimum profit (WEC, 2004). The initial Fund is subsidized by public funds. Other programs partly fund projects, like the EU's PHARE Programme that co-finances projects with the state concerned (mostly Eastern Europe) that rely on the participation of commercial banks (WEC, 2004). The fund subsidizes the interest rate or losses associated with long repayment options, as in the Latvia Energy Efficiency Fund or the Hungarian Energy Efficiency Credit Fund. The US subsidizes rates through state governments (WEC, 2004).

Canada's Municipal Green Fund is a revolving fund that provides loans with very favorable terms to municipalities or private companies that are partnering with municipalities (WEC, 2004). The Fund began in 2000 with $\$ 125$ million Canadian ( $\$ 100$ million 2005 US equivalent), but was increased to $\$ 250$ million Canadian (\$200 million 2005 US equivalent) for 2001-2002.

Two types of funds exist in this scheme: the Green Municipal Enabling Fund (GMEF) which provides funding for feasibility studies and the Green Municipal Investment Fund 
(GMIF) which provides loans and grants for efficiency projects. The GMIF provides loans up to $25 \%$ of the capital costs of a project to the private sector at a rate of $1.5 \%$ above the government bond rate (WEC, 2004). Interest pays for the administration costs (which are limited) as well as grants for highly innovative projects with long payback periods. As expected, feasibility studies under the GMEF were in greater demand at first. As GMEF studies are completed, more GMIF projects are expected, following the initial trends seen (WEC, 2004). Keys to success of this project have been a financially and environmentally experienced staff with a good reputation among the project participants, very low interest rates and intervention into risky innovative projects. The maximum loan is currently set to $25 \%$ of the project capital costs. It is expected that better efficiency gains could be achieved with 100\% financing (WEC, 2004).

Thailand's Energy Conservation (ENCON) Promotion Act helped set up the ENCON Fund. The agreement to start the fund with six financial institutions was signed in 2003 with a total of 2 billion Gaht (\$500 million May 2005 equivalent) (WEC, 2004). The fund is fixed for three years with the intention that at that point the scheme should become self-sustaining without the need for public intervention. This trend has already begun, with more banks applying to become a part of the scheme (WEC, 2004).

The fund is managed by the Department of Alternative Energy Development and Energy Efficiency (DEDE) in cooperation with the six banks. DEDE provides training and technical assistance to the banks throughout the projects and the banks handle the risks of the loans, the bookkeeping, the credit checking and the customer selection. The banks also learn about the benefits of investing in energy efficiency. Interest rate on the fund is negotiated between the lending institution and the customer to cover the lender's management fees and risks (but limit the interest to the customer), but a maximum of 4\% per year is set by ENCON Fund.,. Banks that do well are rewarded under the scheme; evaluations every six months redistribute funds according to the success of each of the banks (WEC, 2004). A facility in any sector many apply, but only large "Designated Buildings" currently qualify under the scheme. DEDE hopes to expand the scheme in the future to include smaller companies. Thus far, 14 of 19 projects have been approved for industry.

\section{Venture Capital}

Venture capital (VC) funds are funds that are well adapted to young and unproven startup companies (and in this case, in the field of energy) who have unpredictable cash inflows and few fixed assets that would otherwise serve as a loan guarantee for typical investment institutions (banks). This type of innovative fund is very limited as the perceived risk is still too great; to date there are no private venture capital funds specializing in energy efficiency (WEC, 2004). There are, however, public venture capital funds such as the UK's Carbon Trust. Australia also has a joint public/private fund specializing in renewables (CVC Reef, 2005). The security of public funds is likely to provide an incentive for private investors to participate in the VC fund (WEC 2004). As in the case of the Carbon Trust's VC Fund, the hope is to exit the VC company as soon as possible. 
A carbon fund based on venture capital is a unique type of this innovative fund which acts like a venture capital company but seeks return on investment in $\mathrm{CO}_{2}$ emission reductions instead of cash. These funds also sometimes provide seed capital or expertise to companies wishing to specialize in low carbon technologies. The objective is to create a market for low carbon technologies developed by companies without the means of marketing them, and provide a suite of financial instruments up to the point of commercial availability of the products.

The UK's Carbon Trust, established in 2001, is a government-funded independent nonprofit organization that is focused on assisting businesses and the public sector to reduce carbon emissions by $60 \%$ by 2050 as outlined in the UK Government's Energy White Paper (UK Department of Trade and Industry, 2003). The Carbon Trust provides interestfree loans to small and medium sized enterprises, funds a local authority energy financing scheme, promotes the government's Enhanced Capital Allowance Scheme (see section 4 ), and has a venture capital team that invests between $£ 250,000$ to $£ 1.5$ million ( $\$ 284,000$ to $\$ 2.8$ million 2005 US equivalent) per deal as a minority stakeholder alongside private sector investors which they bring in. VC investments include earlystage carbon reduction technologies as well as management teams that can deliver low carbon technologies (Carbon Trust, 2005b).

\section{Tax Relief}

Tax relief can be provided either through programs that grant special tax treatment for purchase of specified technologies or through programs that allow tax rebates to industries that meet specified targets. This section discusses tax relief for specific energyefficient technologies. Section III.C provides details regarding programs in Denmark and the UK that provide tax rebates to industries through target-setting voluntary agreement programs.

Tax relief for purchase of energy-efficient technologies can be granted through tax exemptions, tax reductions, and accelerated depreciation. Such schemes are found in 22 countries. In addition, a few states in the U.S. provide tax incentives for specific technologies or energy efficiency, but no programs exist at the federal level at this time.

A common approach is to provide a list of technologies for special tax treatment. Depending upon the specific program, this tax treatment could be: 1) accelerated depreciation where purchasers of qualifying equipment can depreciate the equipment cost more rapidly than standard equipment, 2) tax reduction where purchasers can deduct a percentage of the investment cost associated with the equipment from annual profits, or 3) tax exemptions where purchasers are exempt from paying customs taxes on imported energy-efficient equipment.

\section{Accelerated Depreciation}

Accelerated depreciation programs are found in Canada, Japan, The Netherlands, and Singapore. In Canada, the Accelerated Capital Cost Allowance Class 43.1 allows taxpayers an accelerated write-off at a rate of $30 \%$ for specified energy efficiency and renewable energy equipment. Typically, equipment investments can be depreciated at 
annual rates between 4\% and 20\%. This program, which was introduced in 1996, provides for accelerated write-off for investments in co-generation and specified wastefueled electrical generation systems, active solar systems, small-scale hydroelectric installations, heat recovery systems, wind energy conversion systems, photovoltaic electrical generation systems, geothermal electrical generation systems and specified waste-fueled heat production equipment. In 2001, the program was expanded to include investments related to generation of electricity from blast furnace gas produced at steel mills (Canada Department of Finance, 2004). In addition, the program includes "intangible expenses" such as the costs of pre-feasibility and feasibility studies, negotiation costs, site approval costs, etc. (Government of Canada, 1998). ${ }^{7}$ There is currently discussion regarding how to make the list of technologies more flexible in order to accommodate inclusion of emerging technologies (Canada, Department of Finance, 2004).

In Japan, under the 1993 Energy Conservation and Recycling Assistance Law, an accelerated depreciation allowance equal to $30 \%$ of the acquisition cost is available for investments in heat pumps, floor heaters, CHP systems, district heating and cooling systems, high efficiency electric trains, low emission vehicles, energy-efficient textile manufacturing equipment, solar power systems, small- and medium-size hydro generators, and equipment for producing recycled paper and plastics (Anderson, D., 2002).

The Netherlands also provides the Accelerated Depreciation on Environmental Investment program (VAMIL), which allows an investor to more rapidly depreciate its investment in environmentally-friendly machinery, reducing operating profits and tax payments. This program has been in effect since 1991 and includes equipment that reduces water use, soil and air pollution, noise emissions, waste production and energy use. To qualify, the equipment must have relatively good environmental impacts, be not yet widely accepted in the country, have no negative side effects, and have the potential for a substantial market in the country. The list of qualifying equipment is updated regularly. Costs associated with obtaining advice on the purchased machinery are also subject to accelerated depreciation (IISD, 1994; SenterNovem 2005a).

Under Singapore's Income Tax Act, companies that invest in qualifying energy-efficient equipment can write-off the capital expenditure in one year instead of three. Unlike the Canadian and Dutch programs, however, expenses related to acquiring information or consultant fees for identifying and analyzing the equipment purchase are not included in this program. Replacement equipment, such as new air-conditioning systems, boilers, and water pumps, along with energy-saving equipment such as high efficiency motors, variable speed drive motors, or computerized energy management systems qualify (NEEC, 2005).

\footnotetext{
${ }^{7}$ This is the Canadian Renewable and Conservation Expense. It allows the intangible costs (e.g., feasibility studies, pre-construction expenses, etc.) associated with projects that fall under Class 43.1 either 1) to be expensed the year they are incurred, 2) to be carried forward for deduction in a later year, or 3) to be passed on to investors through Flow Through Share (FTS) agreements. By passing on tax deductions to investors, FTS agreements help encourage investment and facilitate financing (M.K. Jaccard \& Associates, 2004).
} 


\section{Tax Rebates}

Programs in which companies deduct the cost of energy-efficient equipment from their annual profits are found in Japan, Korea (Republic of), The Netherlands, and the UK. Japan's Energy Conservation and Recycling Assistance Law also provides a corporate tax rebate of $7 \%$ of the purchase price of energy-efficient equipment for small and medium-sized firms (WEC, 2001b). In the Republic of Korea, a 5\% income tax credit is available for energy-efficiency investments such as replacement of old industrial kilns, boilers, and furnaces; installation of energy-saving facilities, co-generation facilities, heat supply facilities, or energy-saving equipment; alternative fuel using-facilities; and other facilities that reduce energy by $10 \%$ (UNESCAP, 2000).

\section{Tax Deductions}

In The Netherlands, under the Energy Investment Deduction (Energie Investeringsaftrek, EIA) program, originally $40 \%$ and now $55 \%$ of the annual investment costs of energysaving equipment can be deducted from the fiscal profit during the calendar year in which the equipment was procured, up to a maximum of $107 \mathrm{M} €$. Qualifying equipment is provided on an "Energy List" and the costs associated with obtaining advice for purchased equipment can also be included. Approval is granted by SenterNovem, an agency under the Dutch Ministry of Economic Affairs. The budget for this program in 2005 is $137 \mathrm{M} €$ (Aalbers et al., 2004; SenterNovem, 2005b).

The UK's Enhanced Capital Allowance Scheme allows a business to claim 100\% firstyear tax relief on their spending on qualifying energy-saving technologies specified in the "Energy Technology List" on their income or corporatin tax return. Businesses can write off the entire capital cost of their investments in energy-saving technologies against their taxable profits for the year during which they make the investment (HM Revenue \& Customs, n.d.). The technologies that currently appear on the 2004 Energy Technology List are: air-to-air energy recovery, automatic monitoring and targeting, boilers, combined heat and power (CHP), compact heat exchangers, compressed air equipment, heat pumps for space heating, HVAC zone controls, lighting, motors, pipework insulation, refrigeration equipment, solar thermal systems, thermal screens, variable speed drives, and warm air and radiant heaters (Carbon Trust, 2005c)

\section{Tax Exemption}

A full exemption from Germany's petroleum tax is provided for highly efficient combined heat and power (CHP or cogeneration) facilities that have monthly or annual utilization rates of $70 \%$ or greater (German Federal Ministry for the Environment, Nature Conservation, and Nuclear Safety, 2004).

Romania has a program where imported energy-efficient technologies are exempt from customs taxes and the share of company income directed for energy efficiency investments is exempt from income tax (Alliance to Save Energy et al., n.d.). In November 2000, the Energy Efficiency Law was passed by the Parliament of Romania. The law covers the efficient use of energy in all areas. One element of the law is that "devices, machine tools, equipment and technologies for increasing energy efficiency are exempt of custom taxes" (CEEBICNet Market Research, 2004). 


\section{Evaluations}

Programs that provide tax relief for specific energy-efficiency technologies typically have a large number of participants. During the period 1997 to 1999, almost 14,000 entities in 46 different industrial sectors took advantage of the Dutch EIA program for 15 different technologies (de Beer et al., 2000). Applications for the investment deduction peaked in 2001, when over 28,000 applications representing over $1 \mathrm{~B} €$ in claims were filed (Aalbers, et al., 2004). Japan's Energy Conservation and Recycling Assistance Law resulted in accelerated depreciation of approximately 25,000 pieces of equipment each year during the period 1996 through 1998. The Law's special taxation measures led to increased investment in energy-efficient products from 300 billion yen in 1990 to 800 million yen in 1993 (US\$ 4 billion) (WEC, 2001b).

Decisions regarding the purchase of energy-efficient technologies are typically based more on the cost of the equipment than on the expected cost of energy used to power the equipment. This implies that tax relief for energy-efficient technologies may be more effective than taxing energy per se. However, there are some disadvantages to the tax relief approach, including the fact that they do not provide incentives to conserve reduce energy, can result in large expenditures of public funds, and are subject to a large number of "free-riders", or investors who take advantage of the program even though they would have made the investment without the tax relief (Newell, 2004). Evaluations of the Dutch EIA program found that $33 \%$ of for-profit firms would have purchased the energyefficient technology without the subsidy, while $65 \%$ of non-profits would have made such a purchase. Overall, the study found that "almost half of the firms would have bought the technology even in the absence of the subsidy." Even so, the subsidies did serve another important function of alleviating liquidity constraints (Aalbers, et al., 2004). Overall, the evaluations found that tax relief for energy-efficient technologies "may involve a considerable amount of free riders" but that the amount of free riders differs by technology. Programs should be designed such that they avoid providing tax relief for technologies that are already profitable (de Beer et al., 2000). 


\section{Integrated Policies}

\section{Denmark - $\mathrm{CO}_{2}$ Taxes and Voluntary Agreements}

In 1990, the Danish Parliament established an ambitious target to reduce its national level of $\mathrm{CO}_{2}$ emissions by $20 \%$, relative to the level in 1988 , before 2005 . Under the Kyoto Protocol, and the following EU burden-sharing agreement, a new target has been set to reduce greenhouse gas emissions by $21 \%$ below 1990 levels by 2008-2012, corresponding to a total emission level of 54.9 million ton $\mathrm{CO}_{2}$.

To reach its climate political goals, Denmark has undertaken a succession of integrated greenhouse gas emissions reduction strategies over the years. A central element in these strategies has been the use of household and business energy and $\mathrm{CO}_{2}$ taxation, as a way to provide economic incentives for energy conservation and fuel switching. The business $\mathrm{CO}_{2}$ tax has been combined with subsidies for clean energy technology investments and tax rebates for energy-intensive industries that enter into voluntary agreements.

Taxation has been imposed on the consumption of energy in Denmark since the 1970s. Traditionally the energy taxes have only covered households and non-value added tax (VAT)-registered businesses (including public bodies). In order to preserve international competitiveness and employment energy taxes paid by VAT-registered businesses have been fully reimbursed (except for petrol used in passenger cars).

In 1992, Denmark was one of the world's first countries to introduce a $\mathrm{CO}_{2}$ tax on both household and businesses energy consumption. With the aim of encouraging energy efficiency and switching towards fuels with less $\mathrm{CO}_{2}$ content, the standard tax rate was set at $€ 13.4$ per ton $\mathrm{CO}_{2}$. However, concerns about international competitiveness made it necessary to reimburse $50 \%$ of the effective rate to all businesses. Additional reimbursements furthermore had to be introduced according to the energy intensity of each company. This eventually led to the result that the most energy-intensive companies in practice escaped from paying any $\mathrm{CO}_{2}$ tax at all. Part of the revenues raised by the $\mathrm{CO}_{2}$ tax was used to subsidize business energy conservation projects. All in all, the first Danish $\mathrm{CO}_{2}$ tax was not very environmentally effective. The most energy-intensive businesses were in practice tax exempt, while benefiting from energy conservation subsidies, which no one could really guarantee did not just go to projects that would have been carried out anyway.

In a subsequent Government assessment of the Danish Climate Strategy it was confirmed that Denmark would not reach its $\mathrm{CO}_{2}$ reduction target and that an increase in the business $\mathrm{CO}_{2}$ tax to $€ 26.8$ per ton $\mathrm{CO}_{2}$ would be required to get back on track. The Committee estimated that such an increase would have inconsiderable (and if any only positive) effects on overall employment levels, if the revenues from the tax raise were fed back to the business sector. If the tax were furthermore combined with a gradual introduction, and some minor exemptions for energy intensive industrial processes, international competitiveness could be secured as well (Finansministeriet 1994). 
In 1996, it was decided to increase the total energy and $\mathrm{CO}_{2}$ tax burden on business energy consumption. While the standard $\mathrm{CO}_{2}$ tax rate was kept unchanged, the tax base of the regular energy taxes was extended to cover what was defined as the business use of "space heating", the $\mathrm{CO}_{2}$ tax reimbursement scheme was rearranged and tightened and finally a new system of voluntary energy efficiency agreements introduced. All the extra revenues raised were to be fed back to the business sector, largely through reductions in labor market contributions and grants for energy efficiency investments. The final business energy and $\mathrm{CO}_{2}$ tax system included five levels, as shown in Table 3:

Table 3. 1996 Danish Energy and $\mathrm{CO}_{2}$ Taxes for Industry

\begin{tabular}{|l|l|}
\hline Space heating & $\begin{array}{l}\text { Full energy taxes and } \mathrm{CO}_{2} \text { tax } \\
\left(€ 80.65 \text { per ton } \mathrm{CO}_{2}\right)\end{array}$ \\
\hline Light process, no agreement & $\begin{array}{l}90 . \% \text { of } \mathrm{CO}_{2} \text { tax } \\
\left(€ 12.10 \text { per ton } \mathrm{CO}_{2}\right)\end{array}$ \\
\hline Light process, with agreement & $\begin{array}{l}68 . \% \text { of } \mathrm{CO}_{2} \text { tax } \\
\left(€ 9.20 \text { per ton } \mathrm{CO}_{2}\right)\end{array}$ \\
\hline Heavy process, no agreement & $\begin{array}{l}25 . \% \text { of } \mathrm{CO}_{2} \text { tax } \\
\left(€ 3.40 \text { per ton } \mathrm{CO}_{2}\right)\end{array}$ \\
\hline Heavy process with agreement & $3 . \%$ of $\mathrm{CO}_{2}$ tax \\
& $\left(€ 0.40\right.$ per ton $\left.\mathrm{CO}_{2}\right)$ \\
\hline
\end{tabular}

The use of space heating was to cover "household type" energy consumption, such as the heating and lighting of rooms and the heating of water in kitchens and bathrooms. The distinction between energy used for space heating and for process purposes was laid down in the legislation. The use of all fuels (coal, mineral oil and natural gas) was generally considered as space heating, unless the use was for a range of specific process heating purposes, as defined in the law. The other way around, electricity was generally considered as used for process purposes, unless the use was for specific heating purposes, as defined in the law (like radiators or water heaters) (Larsen, 1999).

Heavy processes were explicitly described in an annex to the $\mathrm{CO}_{2}$ tax law. In order to be included as a heavy process, the effect of a $\mathrm{CO}_{2}$ tax of $€ 6.72$ per ton $\mathrm{CO}_{2}$ on the relevant production unit has to be higher than $3 \%$ of the value added of the unit and at least $1 \%$ of the turn over of the products manufactured by the company. International competition, and competition with national non-energy intensive companies, is furthermore taken into consideration when heavy processes are identified. Including on the list is melting, concentration and drying in cement, steel, mineral wool, clinker, condensed milk and fish meal production (Johannsen, 2002). Following the submission of new evidence by industries, the heavy process list has been expanded over the years.

The energy efficiency agreements, entered by individual companies or associations of companies with the Danish Energy Agency, are made for periods of three years. Between 1996 and 2001, approximately 300 companies entered into such agreements, representing $60 \%$ of total industrial energy consumption in Denmark (Hansen, 2001). Under the agreements, the companies are required to implement all "profitable" energy savings projects, which are defined as projects with payback periods of up to four years, as 
identified in an energy audit or through internal investigations. The energy audits are conducted by authorized energy consultants or by company staff. In any case they must be verified by an independently certified organization. In addition, companies must introduce energy management and motivate staff to ensure that investments in new equipment are energy efficient. Subsidies are provided for up to $30-50 \%$ of the cost of energy efficient investments (Bjørner and Jensen 2000; Johannsen, 2002).

In 1999, a Committee under the Ministry of Finance concluded that the business energy and $\mathrm{CO}_{2}$ taxes created a substantial environmental effect in an economically efficient way, while taking international competitiveness into proper consideration. (Finansministeriet 1999). An independent study has later pointed in the same general direction, concluding that business energy taxes have contributed to an overall reduction in energy consumption levels of $10 \%$. Taken alone, the energy efficiency agreements led to a reduction in energy consumption of $9 \%$ (Bjørner and Jensen 2000). Another assessment has found that the result of voluntary agreements was a reduction in energy consumption of 2 to $4 \%$ of total energy consumption per agreement after three years (thereby exceeding business-as-usual by about $1 \%$ per year) (Togeby et al., 1999). In another evaluation of the agreement system, it has been indicated that most energy efficiency measures would have been pursued, even without the agreement scheme, but the agreement scheme seemed to have speeded up the process (Krarup et al. 1997). In yet another study it was concluded that companies seemed to take energy management more seriously as a result of the agreement schemes (Johannsen and Larsen 2000).

Energy taxes were raised 15 to $20 \%$ in 1999 , as part of an overall package of economic policy measures aiming to cool an economy showing signs of overheating. This in effect meant that the effective rate on business use on space heating increased to $€ 100$ per ton $\mathrm{CO}_{2}$. Later the structure of the business energy and $\mathrm{CO}_{2}$ tax system was changed. First, in order to simplify the system, the standard $\mathrm{CO}_{2}$ tax rate was lowered to $€ 12.10$ per ton $\mathrm{CO}_{2}$, while the regular energy tax rates were increased with a corresponding amount. Table 4 shows the current taxation levels.

Table 4. 1999 Danish Energy and $\mathrm{CO}_{2}$ Taxes for Industry

\begin{tabular}{|l|l|}
\hline Space heating & $\begin{array}{l}\text { Full energy taxes and } \mathrm{CO}_{2} \text { tax } \\
\left(€ 100 \text { per ton } \mathrm{CO}_{2}\right)\end{array}$ \\
\hline Light process, no agreement & $\begin{array}{l}\text { Full } \mathrm{CO}_{2} \text { tax } \\
\left(€ 12.10 \text { per ton } \mathrm{CO}_{2}\right)\end{array}$ \\
\hline Light process, with agreement & $68 \%$ of $\mathrm{CO}_{2}$ tax \\
& $\left(€ 9.20\right.$ per ton $\left.\mathrm{CO}_{2}\right)$ \\
\hline Heavy process, no agreement & $27.78 \%$ of $\mathrm{CO}_{2}$ tax \\
& $\left(€ 3.40\right.$ per ton $\left.\mathrm{CO}_{2}\right)$ \\
\hline Heavy process with agreement & $4.8 \%$ of $\mathrm{CO}_{2} \operatorname{tax}$ \\
& $\left(€ 0.40\right.$ per ton $\left.\mathrm{CO}_{2}\right)$ \\
\hline
\end{tabular}

In a step towards adapting the business energy and $\mathrm{CO}_{2}$ tax system to the new $\mathrm{EU} \mathrm{CO}_{2}$ emissions allowance trading system, a full reimbursement of $\mathrm{CO}_{2}$ taxes paid for heating fuels used in production processes covered by emissions trading was furthermore 
introduced. This removed the $\mathrm{CO}_{2}$ tax in areas were the direct burden of the emissions trading system is expected to be the highest. Enterprises still have to pay $\mathrm{CO}_{2}$ tax for the use of space heating and electricity. The government is currently taking a closer look on the connection between emissions trading and $\mathrm{CO}_{2}$ taxation.

In the latest government report on developments in Denmark's $\mathrm{CO}_{2}$ emissions, a deficit of 20 to 25 million tons $\mathrm{CO}_{2}$ equivalents in order to reach the Kyoto reduction target for year 2008 to 2012 was identified. Ten million of these tons are caused by an expected increase electricity exports.

\section{UK - Climate Change Levy and Climate Change Agreements}

The UK Climate Change Program was established in 2000 to meet both the country's Kyoto Protocol commitment of a $12.5 \%$ reduction in greenhouse gas emissions by 2008 2012 relative to 1990 and the domestic goal of a $20 \% \mathrm{CO}_{2}$ emissions reduction relative to 1990 by 2010 (DEFRA, 2000). A key element of the Climate Change Program is the Climate Change Levy which is an energy tax applied to industry, commerce, agriculture, and the public sector. The levy does not apply to domestic customers or charities. In addition, all oil use and electricity produced through combined heat and power (cogeneration) units or with renewable sources is not taxed. The tax rates are provided in Table 5 below (DEFRA, 2004; Smith 2004).

Table 5. UK Climate Change Levy Tax Rates

\begin{tabular}{|l|l|}
\hline Fuel & \multicolumn{1}{c|}{ Tax Rate $(€)$} \\
\hline Natural gas & $13 € /$ tonne $\mathrm{CO}_{2}$ \\
\hline Coal & $7 € /$ tonne $\mathrm{CO}_{2}$ \\
\hline Electricity & $14 € /$ tonne $\mathrm{CO}_{2}$ \\
\hline
\end{tabular}

The revenues from the levy are returned to the taxed sectors through a $0.3 \%$ reduction in the rate of employer's National Insurance Contributions. In addition, programs that provide financial incentives for adoption of energy efficiency and renewable energy, as well as the Enhanced Capital Allowance Scheme that provides 100\% first year capital allowances for specified energy efficiency investments are also offered to industry, commerce, and the public sector (DEFRA, 2004; see also section II.B.4).

Along with the Climate Change Levy and the financial incentive programs, certain companies can also participate in Climate Change Agreements (CCAs). Through the CCAs, energy-intensive industrial sectors established energy efficiency improvement targets. Companies that meet their agreed-upon target are given an $80 \%$ discount from the Climate Change Levy. The UK's Department of Environment, Food, and Rural Affairs (DEFRA) worked with business sector associations to set the emissions reduction targets that cover the period 2002 to 2012. Targets may be absolute or relative (emission reduced per unit of product produced). The agreements are signed between DEFRA and the industry associations, and between Defra and individual companies. There are 44 sector agreements representing about 5,000 companies and 10,000 facilities. The goal of the CCAs is to reduce carbon dioxide emissions by $2.5 \mathrm{MtC}$ by 2010 , which is ten times the 
estimated savings from the Climate Change Levy without the agreements (Pender, 2004). Companies that do not meet their targets can purchase carbon allowances through the UK Emissions Trading Scheme (DEFRA, 2005a). If companies exceed their target savings, they can sell carbon on the emissions trading market or bank the carbon for future periods.

The Climate Change Programme is projected to result in carbon dioxide reductions between 15 and $25 \mathrm{MtC}$ by 2020 through energy efficiency (8-12 MtC), renewable energy (3-5 MtC), emissions trading (2-4 MtC), and through reductions in the transport sector (2-4 MtC). Such savings would represent a doubling of the rate of energy efficiency improvement experienced during the past 30 years in the UK (Pender, 2004). The Programme is currently under review.

During the first target period (2001-2002) total reductions of $4.3 \mathrm{MtC}$ were realized, which was three times higher than the target for that period (Pender, 2004). Sectors did better than expected because industry underestimated what they could achieve via energy efficiency. When negotiating the targets, most companies believed that they were already energy-efficient. When they actually managed energy because of the CCA targets, companies saved more than they thought that they could, especially through improved energy management (Future Energy Solutions, 2004). Industry realized total reductions of $4 \mathrm{MtC}$ during the second target period, more than double the target set by the government (DEFRA, 2005b). The 2004 review of the agreements took into account the better-than-anticipated performance and resulted in a tightening of targets for the final three target periods compared to the original agreements (Future Energy Solutions, 2005).

\section{Emissions Trading}

Emissions trading schemes are based on the allocation of an authorization to emit a ton of a pollutant. A limited number of emission permits that represent an aggregate emissions level below current practice are allocated, creating a market in which permits have a positive value (Gehring and Streck, 2005). The basis of emission trading, or the use of tradable permits, as a useful regulatory tool stems from the notion that all parties will benefit from free and voluntary trades. Markets are institutions for transfers of property rights. The concept of tradable permits in environmental management first appeared in 1968 (Koutstaal, 1999).

There are two types of emissions trading systems: cap-and-trade and baseline-and-credit systems. Most implemented trading systems are cap and trade systems (except for the flexible mechanisms used in the Kyoto Protocol), which are based on an absolute emissions limit for a specified time period. Emission allowances, which represent a defined emission amount, are either granted outright or auctioned to participating entities. Under a baseline-and-credit system, emissions reduction credits are granted against a projected baseline of emissions and these credits can be used to meet an absolute target (Gehring and Streck, 2005). 
A wide variety of activities are amenable to the establishment of rights and trading. Emissions allowances establish a volume of permitted emissions, give an enterprise permits for that volume, and define the terms of trading. Enterprises may be given emissions reduction credits when they reduce emissions below allowable levels. They trade these reduction credits with others who will not reduce their emissions to allowable levels. Rules are established that define the property rights implied by the permits, such as how long they are active, whether they can be banked and used later, whether some spatial trades are not allowed, and trading ratios across locations or types of activities (Farber, 2004).

Permit and rights trading can have adverse consequences when the regulatory objective is to ensure an acceptable ambient concentration; for example, unrestricted trading of nonuniformly mixed pollutants may create "hot spots" where ambient conditions exceed objectives (e.g mercury emissions from coal-fired power stations). For emissions of most greenhouse gases that have a global impact and have limited local environmental impact, this limitation would be less problematic.

Other problems with emission trading are especially associated with the design of the program, e.g. number of market participants, monopolies or excessive market power of participants, validity of emission permits over time, allocation of emission permits, transaction costs, and many other details (Farber, 2004; Tietenberg, 1999).

Tradable permits have been used in a variety of environmental regulatory applications in the United States. The first application was in air non-attainment areas in the early 1970s. In the course of phasing out lead in gasoline, U.S. refineries were allowed to trade lead content (Farber, 2004).

U.S. power plants have participated since the mid-1990s in an active sulfur dioxide trading program under the Clean Air Act's Acid Rain Program. In the acid rain program, emission rights were "grandfathered" on the basis of historic emissions of existing power stations. Basically, emissions allowances were calculated based on allowable emissions per unit of fuel input times average fuel consumption. Allowances are for annual emissions, but are bankable for a limited period. A long-term reduction target of the total number of allowances was set. Plants with emissions less than available allowances can trade with plants that exceed their allowances. Furthermore, the U.S. Environmental Protection Agency holds some allowances and offers them at annual auctions. This mechanism allowed new entrants to purchase emission rights, and also is a good price indicator of the actual market value of emission allowances, improving the working of the market.

The SOx trading program is considered a success, as it led to a faster reduction in total SOx emissions from power producers, at a far lower cost than expected. The cost reduction was partially due to the availability of low-cost low-sulfur coal (Farrell, 2005), and partially due to the bankable character of the allowances. Furthermore, the program supported the optimal use of power stations with low emissions (i.e. with scrubbers 
installed), improve the operation and effectiveness of the scrubbers and scrubberequipped power stations, while reducing the use of more polluting power stations.

The experience with the SOx trading system led eight northeastern U.S. states to establish a NOx trading program, while the South Coast Air Quality Management District in southern California established a Regional Clean Air Incentives Market (RECLAIM) in the early 1990s. Emissions allowances for NOx and SOx were established and sources were allowed to trade emissions reduction credits, where trading ratios were set for trades between geographic areas (Farber, 2004; Farrell, 2005).

In January 2005, the European Union Greenhouse Gas Emission Trading Scheme (EU ETS) commenced operation as the largest multi-country, multi-sector GHG emission trading scheme worldwide (Directive 2003/87/EC) (European Commission, 2005). The EU ETS is the first international trading system for $\mathrm{CO}_{2}$ emissions in the world. It covers some 12,000 installations representing close to half of Europe's emissions of $\mathrm{CO}_{2}$. The EU ETS includes all power stations, petroleum refineries, iron and steel plants, coke ovens, cement, glass and ceramic plants, as well as all combustion installations over 20 MWth. ${ }^{8}$

The aim of the EU ETS is to help EU Member States achieve compliance with their commitments under the Kyoto Protocol. Letting participating companies buy or sell emission allowances means that the targets can be achieved at least cost. The legal framework of the trading scheme does not regulate how and where the market in allowances takes place. Companies with commitments may trade allowances directly with each other, or they may buy or sell via a broker, bank or other allowance market intermediary. A number of exchanges have been set up to facilitate the trade in emission allowances.

While the European Commission has written the directive, allocation of the allowances is done by each member state, which has led to differences in interpretations, allocation rules, and the level of allocations. Generally, allocations are based on the historical trends in emissions, expected production levels, and the $\mathrm{CO}_{2}$ emission reduction commitment of the member state under the Kyoto Protocol. Countries have also reserved a certain amount of emission allowances for new entrants.

The EU ETS entered into force in January 2005 for the first trading period (2005-2007). The volume of traded allowances is slowly increasing, but still very small compared to the total amount of allowances in the EU. In April 2005, most of the National Allocation Plans (NAP) were approved by the commission.

It is too early to draw conclusions on the success of the EU ETS. The European Commission is currently performing a mid-term evaluation of the EU ETS. By early 2006, the revised rules for the EU ETS for the second trading period (2008-2012) have to

\footnotetext{
8 The exact interpretation and definition of combustion installations of the European Commission guidelines has varied from country to country. Hence, in most countries combustion installations only include boilers, whereas several countries also include other installations like furnaces and driers in ETS.
} 
be established. Various member states and the Commission are developing proposals and initiatives to improve the EU ETS. Key items that are being discussed are the participation of other sectors (e.g. chemicals), the inclusion of small installations (i.e. a large number of small installations is responsible for only a small fraction of the emissions under EU ETS), harmonized rules for allocation (e.g. benchmarking), the inclusion of credits from flexibility mechanisms, the new entrants reserve within the current NAPs, as well as other more technical aspects of the EU ETS.

The Climate Change Plan for Canada includes development of a tradable permit system to provide an incentive for GHG emission reduction. A pilot "voluntary" emissions trading system, the Pilot Emission Removals, Reductions and Learning Initiative (PERRL), is currently operating. In this program, which will run until the end of 2007, the Canadian government buys the rights to verified GHG emission reductions from eligible projects for a fixed price per tonne of $\mathrm{CO}_{2}$ reduced (M.K. Jaccard \& Associates, 2004).

The Kyoto Protocol allows greenhouse gas trading through several provisions. These provisions all assume a system based on baselines and reductions, where the reductions can be traded. The Joint Implementation provision allows Annex I countries, larger developed countries, to acquire emissions reduction units from other Annex I countries. These reduction units can be based on projects that either reduce emissions or increase sinks for greenhouse gases. The Clean Development Mechanism allows Annex I countries to invest in emissions reduction or sink projects in non-Annex I countries in order to obtain emissions reduction units. International Emissions Trading provisions then allow Annex I countries to trade with one another to meet greenhouse gas targets. 


\section{Industrial Energy Efficiency Best International Practices}

This report has provided an overview of a number of tax and fiscal policies for encouraging investment in energy-efficient industrial equipment and processes. While it is sometimes difficult to identify the country or program that represents international best practice for each specific policy, it is clear that the most effective policies combine a number of tax and fiscal programs in an effort to provide a clear economic signal to industry that investments in energy efficiency are a high priority.

The report shows that many countries use energy or $\mathrm{CO}_{2}$ taxes to provide an incentive to industry to improve the energy management at their facilities through both behavioral changes and investments in energy-efficient equipment. The most well-designed energy or $\mathrm{CO}_{2}$ tax programs recycle the revenue back into the economy, use the revenue to provide tax incentives for energy-efficiency investments or to provide information and auditing programs, and provide tax reductions for industries that meet negotiated energy efficiency targets.

Fiscal policies such as grants or subsidies for investments in energy efficiency, subsidized audits, loans, and tax relief, are used in many countries to promote industrial energy efficiency investments. Simple, transparent processes with limited transaction costs are essential for all fiscal policies or the costs of participation in the program will outweigh the benefits for the enterprise. Targeting audiences will limit free-ridership and inform intended customers of the energy efficiency program or policy. Linking programs to cost-effectiveness criterion or voluntary agreements have also proven successful in many countries.

Subsidized audit programs for industry are the most popular policy employed around the world to induce efficiency investments. In such assessment programs, auditors need a high level of expertise in the applicable production processes as well as energy efficiency. Targeting specific customers can overcome certain obstacles encountered in audit programs around the world, such as simply a lack of knowledge of the program or free-ridership.

Although public loans are less popular than outright energy efficiency subsidies, innovative funding mechanisms such as ESCOs, guarantee funds, revolving funds, and venture capital funds are growing in popultarity. For loans sponsoring energy efficiency projects, successful uptake requires interest rates and perceived risk to private institutions to be minimized. Because of the risks involved with the innovative funding programs, fund managers for these programs need expertise in both energy/environmental issues and financial issues, as well as international experience where projects span multiple countries. Projects selected should have a high threshold for qualification, i.e., be high quality and bankable.

Tax relief programs such as accelerated depreciation, tax reductions, and tax exemptions are used to guide investors toward purchases of more energy efficient equipment, but it is 
important to design such programs so that they don't provide tax relief for technologies that are already profitable.

Overall, the best practices internationally are those that combine tax and fiscal policies into an integrated program that provides clear economic signals and incentives that raise management awareness so that industries are motivated to reduce the costs associated with consumption of polluting energy sources and to improve the energy efficiency of their facilities.

\section{Acknowledgments}

This work was supported by the Energy Foundation's China Sustainable Energy Program through the U.S. Department of Energy under Contract No. DE-AC03-76SF0098. We would like to thank Zhang Ruiying of the Energy Foundation, Wu Xiaohua of the China Energy Conservation Investment Corporation (CECIC), and Su Ming and Fu Zhihua of the Research Institute of Fiscal Science (RIFS) for their guidance during the preparation of this report. We would also like to thank Marie Pender of the UK's Department of Enviroment, Food, and Rural Affairs (DEFRA) and Jacob Klok of the Danish Ministry of Taxation for their contributions. Finally, we would like to thank Lin Jiang and Mark Levine of Lawrence Berkeley National Laboratory for their helpful review of this report. 


\section{References}

Aalbers, R.F.T., de Groot, H.L.F., Vollebergh, H.R.J., 2004. "Effectiveness of Subsidizing Energy Saving Technologies: Evidence from Dutch Panel Data," 6th IAEE European Energy Conference on Modelling in Energy Economics and Policy. http://www.saee.ch/saee2004/Aalbers DeGroot Vollebergh IAEE.pdf

Alliance to Save Energy, Municipal Network for Energy Efficiency, U.S. Agency for International Development, U.N. Economic Commission for Europe, n.d. Survey of Energy Efficiency Laws and Policy Provisions in 22 Countries and Two Regions: Recommendations for Policymakers. Washington, DC: Alliance to Save Energy.

American Council for an Energy-Efficient Economy, 2004. Summary Table of Public Benefit Programs and Electric Utility Restructuring. Washington DC: ACEEE. http://www.aceee.org/briefs/mktabl.htm

Anderson, D., 2002. Progress Toward Energy Sustainability in OECD Countries. Helio International. http://www.helio-international.org/Helio/anglais/reports/oecd6.html\#top

Anderson, Soren T., and Richard G. Newell. 2004. Information programs for technology adoption: the case of energy-efficiency audits.

Apollo Alliance, 2004. Public Benefit Funds: General Description.

http://www.apolloalliance.org/regional_projects/model_financing_strategies/pbfs.cfm

Bach, Stefan et al., 2001a. Die ökologische Steuerreform in Deutschland. Eine modellgestützte Analyse ihrer Wirkungen auf Wirtschaft und Umwelt. Heidelberg: Physica Verlag

Bach, Stefan et al., 2001b. Wirkungen der ökologischen Steuerreform in Deutschland, in: Wochenbericht des DIW, Heft 14, 220-225

Bjørner, T.B. and Jensen, H.H., 2000. Industrial Energy Demand and the Effect of Taxes, Agreements and Subsidies. Copenhagen: AKF Forlaget.

Bjørner, T.B. and Jensen, H. H., 2002. "Energy Taxes, Voluntary Agreements and Investment Subsidies - A Micro-Panel Analysis of the Effect on Danish Industrial Companies' Energy Demand," Resource and Energy Economics 24: 229-249.

Bode, W., Worrell, E., Berkhout, P. H. G., Giesberger, D., Paape, A.H., and Velthuijsen, J.W., 1998. Onderzoek naar Effecten van de Regulerende Energiebelasting bij Bedrijven, Stand van Zaken einde 1997, (Study of the Effects of the Regulating Energy Taxation for Enterprises: Status at the end of 1997), Stichting voor Economisch Onderzoek, Universiteit van Amsterdam, Amsterdam.

Canada, Department of Finance, 2004. Background Information: Class 43.1 (Income Tax Regulations). http://www.fin.gc.ca/activty/consult/class431-2e.html 
Carbon Trust, 2005a. Carbon Trust Energy Surveys.

http://www.thecarbontrust.co.uk/energy/pages/page_282.asp, accessed 4/12/05.

Carbon Trust, 2005b. Develop Low Carbon Technology: Venture Capital.

http://www.thecarbontrust.co.uk/carbontrust/low_carbon_tech/dlct2_4.html

Carbon Trust, 2005c. The Enhanced Capital Allowance Scheme: Products and Claims. http://www.eca.gov.uk/etl/page.asp?pagecode $=000100020001$

CEEBICNet Market Research, 2004. Energy Efficiency in Romania. http://www.mac.doc.gov/ceebic/countryr/Romania/EnergyEfficiency.htm

China Daily, 2005. Report on the Work of the Government.

http://www.chinadaily.com.cn/english/doc/2005-03/15/content_425079.htm

CVC Reef, 2005. Website: Welcome to CVC Reef.

$\mathrm{http}: / /$ www.cvcreef.com.au/ssl/axs/5/2.asp?secID=2

Danish Energy Agency, 2000. Green Taxes for Trade and Industry - Description and Evaluation. http://www.ens.dk/graphics/Publikationer/Energibesparelser_UK/Green-taxuk-rap.PDF

Danish Energy Authority, 2005. Website, available at http://www.ens.dk. Accessed on $4 / 13 / 05$.

De Beer, J., Kerssemeeckers, M.M.M., Aalbers, R.F.T., Vollebergh, H.R.J., Ossokina, J., de Groot, H.L.F., Mulder, P., and Blok, K., 2000. Effectiviteit Energiesubsidies: Onderzoek naar de effectiviteit van enkele subsidies en fiscale regelingen in de periode 1988-1999 (Effectiveness Energy Subsidies: A Study of the effectiveness of several subsidy and fiscal instruments in the period 1988-1999.) Utrecht, The Netherlands: Ecofys.

Department of Environment, Food, and Rural Affairs (DEFRA), 2000. Climate Change: The UK Programme - Summary. http://www.defra.gov.uk/environment/climatechange/cm4913/index.htm

Department of Environment, Food, and Rural Affairs (DEFRA), 2004. Climate Change Agreements: The Climate Change Levy. http://www.defra.gov.uk/environment/ccl/intro.htm

Department of Environment, Food, and Rural Affairs (DEFRA), 2005a. UK Emissions Trading Scheme.

http://www.defra.gov.uk/environment/climatechange/trading/uk/index.htm

Department of Environment, Food, and Rural Affairs (DEFRA), 2005b. News Release: Industry Beats CO2 Reduction Targets. 21 July 2005. 
http://www.defra.gov.uk/news/2005/050721b.htm

Ekins, P., 1996. Environmental Taxes \& Charges: National Experiences \& Plans: Report of the European Workshop held at the Foundation, Dublin, on 7-8 February 1996, Loughlinstown, Co., Dublin, Ireland. http://www.colby.edu/personal/t/thtieten/ecotaxation.htm

Energy Efficiency Operation Exchange Program, World Bank, 2000. Energy Efficiency Fund Practitioners Workshop Summary. Washington, D.C.: The World Bank, 12.

Eto, Joe, Chuck Goldman, and Steve Nadel, 1998. Ratepayer-Funded Energy-Efficiency Programs in a Restructured Electricity Industry: Issues and Options for Regulators and Legislators. Berkeley, CA: Lawrence Berkeley National Laboratory (LBNL-41479).

European Commission. 2005. The European Union Greenhouse Gas Emission Trading Scheme. http://europa.eu.int/comm/environment/climat/emission.htm

Farber, S. 2004. "Market-Based Instruments, Overview," In: Cutler J. Cleveland (Ed.), Encyclopedia of Energy, Elsevier Science Inc., New York, 2004, Pages 759-768.

Farrell, A.E., 2005. Review of Market-based Incentives for Consideration of Applications in California. California Energy Commission, Sacramento, CA (Report CEC-500-200512)

Faure, Michael G., and Günter Heine. 2002. Criminal Penalties in EU Member Stats' Environment Law. Maastricht: Maastricht European Institute for Transnational Legal Research; Berne: Institute for Criminal Law and Criminology, University of Berne.

Federal Energy Management Program, 2005. Energy-Efficiency Funds and Demand Response Programs, California.

(http://www.eere.energy.gov/femp/program/utility/utilityman_em_ca.cfm).

Finansministeriet, 1994. Grønne afgifter og erhvervene. Schultz Forlag.

Finansministeriet, 1999. Evaluering af grønne afgifter og erhvervene. Schultz Forlag.

FOS, 2005. EFR in Italy. http://www.eco-tax.info/5EUecotax/index.html

http://www.foes-ev.de/GBNnews5/3artike19.html

Future Energy Solutions, AEA Technology, 2004. Climate Change Agreements - Results of the First Target Period Assessment. Version 1.2.

http://www.defra.gov.uk/environment/ccl/pdf/cca_aug04.pdf

Future Energy Solutions, AEA Technology, 2005. Climate Change Agreements - Results of the Second Target Period Assessment. Version 1.0.

http://www.defra.gov.uk/environment/ccl/pdf/cca_jul05.pdf 
Galitsky, C., Price, L., and Worrell, E., 2004. Energy Efficiency Programs and Policies in the Industrial Sector in Industrialized Countries. Berkeley, CA: Lawrence Berkeley National Laboratory (LBNL-54068).

Gehring, M.W. and Streck, C., "Emissions Trading: Lessons From SOx and NOx Emissions Allowance and Credit Systems Legal Nature, Title, Transfer, and Taxation of Emission Allowances and Credits," Environmental Law Reporter: News \& Analysis. http://www.globalpublicpolicy.net/fileadmin/gppi/Streck_ELR_2005.pdf

German Federal Ministry for the Environment, Nature Conservation and Nuclear Safety, 2004. The Ecological Tax Reform: Introduction, Continuation and Development into an Ecological Fiscal Reform.

http://www.bmu.de/files/pdfs/allgemein/application/pdf/oekost_en.pdf

Government of Canada, 1998. Tax Incentives for Business Investments in Energy Conservation and Renewable Energy.

http://www2.nrcan.gc.ca/es/erb/erb/english/View.asp?x=469\&oid=111

Greenhouse Gas Abatement Program (GGAP), 2005. Website. Available at:

http://www.greenhouse.gov.au/ggap/index.html. Accessed 2005.

Hansen, M.D., 2001. "The Danish Experience with Efficiency Improvement in Industrial and Commercial Sectors," Workshop on Best Practices in Policies and Measures, 8-10 October 2001, Copenhagen.

Harris, Phyllis. 2004. EPA FY 2004 End of Year Enforcement \& Compliance Assurance Results. Presentation at GFSD Conference on Economic Aspects of Environmental Compliance Assurance, 2-3 December. Paris: OECD.

HM Revenue \& Customs, n.d. ECA - 100\% Enhanced Capital Allowances for EnergySaving Investments.

http://www.hmrc.gov.uk/capital_allowances/eca_guidance.htm\#claimingfya

Hopper, N., C. Goldman and J. McWilliams (Lawrence Berkeley National Laboratory), D. Birr (Synchronous Energy Solutions), K. McMordie Stoughton (Pacific Northwest National Laboratory), 2005. Public and Institutional Markets for ESCO Services: Comparing Programs, Practices and Performance. Lawrence Berkeley National Laboratory: Berkeley, CA (LBNL-55002). March 2005.

Huglo Lepage \& Partners Counsel. 2003. Criminal Penalties in EU Member States' Environmental Law. Final Report, ENV.B.4-3040/2002/343499/MRA/A. Paris: Huglo Lepage \& Associés Conseil. 15 September.

International Energy Agency (IEA), 2004a. Renewable Energy. Market \& Policy Trends in IEA Countries. Paris: IEA. 
International Energy Agency (IEA), 2004b. Renewable Energy Policy Review, Sweden. Paris: IEA..

International Energy Agency (IEA), 2005. Dealing with Climate Change Database. Available at: http://www.iea.org/textbase/pamsdb/search.aspx?mode=cc.

International Institute for Sustainable Development (IISD), 1994. Accelerated Depreciation of Environmental Investments in the Netherlands. http://www.iisd.org/greenbud/acceler.htm

International Network for Environmental Compliance and Enforcement (INECE). March 2005. Staff memo. Washington, D.C.: INECE.

International Network for Environmental Compliance and Enforcement (INECE). 2005. INECE web page: Civil Penalty Policies.

Jendrośka Bar \& Partners, Environmental Management and Law Association, and Milieu Ltd. 2004. Study on Measures Other Than Criminal Ones in Cases Where Environmental Community Law Has Not Been Respected in a Few Candidate Countries: Summary Report. Prepared for the European Commission (DG Environment) Contract no. B43040/2003/369100/MAR/A.3.

Johannsen, K.S., 2002. "Combining Voluntary Agreements and Taxes - An Evaluation of the Danish Agreement Scheme on Energy Efficiency In Industry," Journal of Cleaner Production 10: 129-141.

Johannsen K. and Larsen, A., 2000. Voluntary Agreements - Implementation and Efficiency. The Danish Country Study. Case Studies in the Sectors of Paper and Milk Condensing. Copenhagen: AKF Forlaget.

Johnson, J., 1998. "EPA Fines Engine Makers," TTNews.com. http://www.ttnews.com/members/printEdition/0000164.html

Kemp, David of the Minister for the Environment and Heritage and Macfarlane, Ian of the Minister for Industry, Tourism and Resources, 2003. Funding for Substantial Greenhouse Gas Abatement Projects. Joint media release, May 29, 2003.

Klok, J., 2002. Negotiating EU CO2/Energy Taxation: Political Economic Driving Forces and Barriers. AKF Forlaget.

http://www.akf.dk/eng2002/pdf/negotiatingEUCO2.pdf

Koutstaal, P. 1999. "Tradable Permits in Economic Theory," In: J.C.J.M. van den Berg (Ed.), Handbook of Environmental Resource Economics. Edward Elgar Publishing, pp. 265-274. 
Kræmer, Trine Pipi and Lajla Stjernström, 1997. Energy Policy Instruments Description of Selected Countries. Available at http://www.akf.dk/index eng.html

Krarup, S.; M. Togeby and K. Johannsen, 1997. De første aftaler om energieffektivisering - erfaringer fra 30 aftaler indgået i 1996. Working paper. Copenhagen: AKF Forlaget.

Kushler, Martin, Dan York, and Patti Witte, 2004. Five Years In: An Examination of the First Half-Decade of Public Benefits Energy Efficiency Policies. Washington, DC: American Council for an Energy Efficient Economy (Report no. U041).

Larsen, H., 1999. Environmental Taxes: Recent Developments in China and OECD Countries. Paris: OECD.

Lutz, C. And Meyer, B. 2001. Wirkungen der ökologischen Steuerreform auf Wirtschaft und Umwelt in Deutschland Ergebnisse von Simulationsrechnungen mit dem umweltökonomischen Modell PANTA RHEI. GWS Discussion Paper 2001/1. Osnabrück: Gesellschaft für Wirtschaftliche Strukturforschung

M.K. Jaccard \& Associates, 2004. Case Study on Fiscal Policy and Energy Efficiency: Baseline Study. Prepared for The National Round Table on the Environment and the Economy. $\quad \mathrm{http} / /$ www.nrtee-trnee.ca/eng/programs/Current_Programs/EFREnergy/Case_Studies/200406_Energy-Efficiency-CS/200406_Energy-Efficiency-CSEA_1-Introduction_E.htm

Ministry of Finance, 2005. Norway: Exemptions from Green Taxes in Norway. http://www.dep.no/fin/english/topics/p4500279/p4500285/006041-990408/dok-bn.html

Ministry of Housing, Spatial Planning and Environment, 2004. The Netherlands' Tax on Energy. Questions and Answers. The Hague, The Netherlands. Accessed 05-02-05. http://www2.vrom.nl/docs/internationaal/Energytax2004.pdf

Ministry of Trade and Industry, 2005. Finland.

http://www.ktm.fi/index.phtml?menu_id=193\&lang=3\&fs=10.

MURE II, 2005. MURE (Mesures d'Utilisation Rationnelle de l'Energie) Database. Available at: http://www.isis-it.com/mure/index.htm. Accessed 4/13/05.

Nadel, Steve, Neal Elliott and Miriam Pye, 1997. Serving the industrial customer: Emerging directions for utility-related energy efficiency services. 1997 ACEEE Summer Study on Energy Efficiency in Industry, Proceedings, pp. 395-407. Washington, DC: American Council for an Energy Efficient Economy.

Nakata, T. and A. Lamont, 2001. "Analysis of the Impacts of Carbon Taxes on Energy Systems in Japan," Energy Policy, 29(2), 159-166. 
National Development and Reform Commission, 2004. China Medium and Long-Term Energy Conservation Plan. http://www.beconchina.org/energy_saving.htm

National Energy Efficiency Committee (NEEC), 2005. Incentive Scheme: One-Year Accelerated Depreciation Allowance for Energy Efficient Equipment and Technology. http://www.neec.gov.sg/incentive/home.shtm

Natural Resources Canada (NRCan), 2005. Website. Information about the Canadian Industry Program for Energy Conservation (CIPEC) available at: http://oee.nrcan.gc.ca/corporate/incentives.cfm?attr $=0$, accessed on 4/13/05.

Newell, R. G., 2004. "Energy Efficiency Challenges and Policies," Proceedings of The 10-50 Solution: Technologies and Policies for a Low-Carbon Future. The Pew Center on Global Climate Change and the National Commission on Energy Policy. http://www.pewclimate.org/docUploads/10\%2D50\%5FNewell\%2Epdf

Oikonomou, V. and Patel, M., 2004. An Inventory of Innovative Policies and Measures for Energy Efficiency. Phase 1 of the EU SAVE "White and Green" Project. Utrecht, The Netherlands: Universiteit Utrecht.

OPET Network, 2001. Danish Legislation in the Field of Renewable Energy. http://www.opet.dk/uk-dk-resleg.htm

Organization for Economic Co-Operation and Development (OECD). 2002. Environmental Performance Reviews: Japan. Paris: OECD.

Organization for Economic Co-Operation and Development (OECD) and Energy Information Administration (IEA), 2003. Policies to Reduce Greenhouse Gas Emissions in Industry - Successful Approaches and Lessons Learned: Workshop Report. Paris: $\mathrm{OECD} / \mathrm{IEA}$.

Pender, M., 2004. UK Climate Change Agreements. Presentation to China Iron and Steel Association Delegation.

Perry, E., 2004. Energy Efficiency for Commercial and Industrial Buildings. http://www.dps.state.ny.us/ElizabethPerry.pdf

Pershing, J., 2000. Common Approaches: Taxes, Trading, and Negotiated Agreements. Pew Center/RIIA Conference on Innovative Policy Solutions to Global Climate Change. Washington DC.

http://www.pewclimate.org/docUploads/pershing\%5Fpresentation\%2Epdf

Pohl, C. and Gisler, P., 2002. Barriers and Opportunities in Realizing Sustainable Energy Concepts - An Analysis of Two Swiss Case Studies. ETH Zentrum. Zurich, Germany. 
Price, L. Jiang, Y., Worrell, E., Du, W., Sinton, J.E, 2003. Development of an Energy Conservation Voluntary Agreement Pilot Project in the Steel Sector in Shandong Province: Report to the State Economic and Trade Commission, People's Republic of China. Berkeley, CA: Lawrence Berkeley National Laboratory (LBNL-51608).

ProSus, 2005. Key Policies for Sustainable Governance. http://www.prosus.uio.no/susnord/norway/national_authorities/key_policies.htm

Ragwitz, M., C. Huber, C., Resch, G., Faber, T., Voogt, M., Coenraads, R., Bodo, P., 2004. FORRES 2020: Analysis of Renewable Energy's Evolution up to 2020. Commissioned by the European Commission, DG TREN. Karlsruhe, Germany.

REC, 2000. A Review of Carbon and Energy Taxes in EU. http://www.rec.org/REC/Programs/SofiaInitiatives/EcoInstruments/GreenBudget/GreenB udget6/carbon.html.

Ren, Yong. 2000. Japanese approaches to environmental management: Structural and institutional features. International Review for Environmental Strategies 1(1): 79-96.

Royal Society, 2002. Economic Instruments for the Reduction of Carbon Dioxide Emissions. London: The Royal Society.

http://www.world-nuclear.org/policy/royalsociety-emissions.pdf

Scottish Energy Efficiency Office (SEEO), 2005. Website, available at: http://www.energy-efficiency.org/index.jsp, accessed 4/14/05.

Scrimgeour, F., Oxley, L., and Fatai, K., 2005. "Reducing Carbon Emissions? The Relative Effectiveness of Different Types of Environmental Tax: The Case of New Zealand," Environmental Modelling and Software 20: 1439-1448.

SenterNovem, 2005a. MIA and Vamil: Tax Relief for Investments in Environmental Friendly Machinery. http://www.senternovem.nl/mia/Topnavigatie/English.asp

SenterNovem, 2005b. EIA: Tax relief for investments in energy-saving equipment and sustainable energy. http://www.senternovem.nl/eia/Topnavigatie/English.asp

Sinton, J.E., Levine, M.D., and Wang, Q., 1998. "Energy Efficiency in China: Accomplishments and Challenges," Energy Policy, Vol. 26, No. 11: 813-829.

Sinton, J.E. and Levine, M.D., 1994. "Changing Energy Intensity in Chinese Industry," Energy Policy 22 pp.239 255.

Sinton, J.E. and Levine, M.D., 2005. Review of Penalties for Violations of Environmental Statutes in Selected Countries. Berkeley, CA: Lawrence Berkeley National Laboratory (LBNL-57295). 
Smith, S., 2004. The UK Climate Change Levy and Ecological Tax Reform. University College London. http://www.eco-tax.info/3events/index.html

Swedish Environmental Protection Agency (SEPA), 1997. Environmental Taxes in Sweden - Economic Instruments of Environmental Policy. Report 4745. Stockholm, Sweden.

Switzer, Sheldon, 2002. "Public benefits charges to fund resource acquisition programs: An Orwellian tale," The Electricity Journal, 15(8): 46-53.

Tietenberg, T. 1999. "Lessons from Using Transferable Permits to Control Air Pollution in the United States," in: J.C.J.M. van den Berg (Ed.), Handbook of Environmental Resource Economics. Edward Elgar Publishing, pp. 275-292.

Togeby, M., Johannsen, K., Ingrslev, C., Thingvad, K., and Madsen, J., 1999. "Evaluations of the Danish Agreement System," Proceedings of the 1999 American Council for an Energy-Efficient Economy Summer Study on Energy Efficiency in Industry. Washington, DC: ACEEE.

UK Department of Trade and Industry, 2003. Our Energy Future: Creating a Low Carbon Economy. http://www.dti.gov.uk/energy/whitepaper/ourenergyfuture.pdf

United Nations Economic and Social Commission for Asia and the Pacific (UNESCAP), 2000. Promotion of Energy Efficiency in Industry and Financing of Investments. http://www.unescap.org/esd/energy/publications/finance/index.html

U.S. Department of Energy (DOE) Office of Industrial Technologies (OIT), 2005. Industrial Technologies Program: BestPractices: Plant Assessments. http://www.oit.doe.gov/bestpractices/assessments.shtml, accessed 4/12/05.

U.S. Environmental Protection Agency (EPA). 2004. Civil Monetary Penalty Inflation Adjustment Rule, 40 CFR Parts 19 and 27. Federal Register 69(30): 7121-7127. 13 February.

U.S. Environmental Protection Agency, 2005a. Compliance and Enforcement. http://www.epa.gov/compliance/

U.S. Environmental Protection Agency, 2005b. Project Ideas for Potential Supplemental Environmental Projects. Washington DC: U.S. EPA.

http://www.epa.gov/compliance/resources/policies/civil/seps/sepprojectidealist063005.pdf

U.S. Environmental Protection Agency, Office of Enforcement and Compliance Assurance (USEPA/OECA), 2004a. Cases and Settlements.

http://cfpub.epa.gov/compliance/cases/

U.S. Environmental Protection Agency, Office of Enforcement and Compliance Assurance (USEPA/OECA), 2004b. Modifications to EPA Penalty Policies to Implement 
the Civil Monetary Penalty Inflation Adjustment Rule. Washington, D.C.: USEPA Memorandum. 21 September.

U.S. Environmental Protection Agency, Office of Enforcement and Compliance Assurance (USEPA/OECA), 2005. Accomplishment Reports.

http://cfpub.epa.gov/compliance/resources/reports/accomplishment/details.cfm

Walsh, M., 2005. Personal communication, 17 March 2005.

Woods, Michael, and Richard Macrory. 2003. Environmental Civil Penalties: A More Proportionate Response to Regulatory Breach. London: Centre for Law and the Environment, University College London.

Wooley, D., 2005. Personal communication, 18 March 2005.

Wooley, David R., and Elizabeth M. Morss. 2002. Clean Air Act Handbook. $12^{\text {th }}$ edition. Albany, N.Y.: Young Sommer LLC.

World Energy Council, 2001a. Energy Efficiency Policies and Indicators, London: WEC.

World Energy Council, 2001b. Japan: Extract from the Survey of Energy Resources. London: WEC. http://www.worldenergy.org/wec-geis/edc/countries/Japan.asp\#top

World Energy Council, 2003. Survey on Energy Efficiency Policy Measures. London: WEC.

World Energy Council, 2004. Energy Efficiency: A Worldwide Review - Indicators, Policies, Evaluation. London: WEC.

Xie Xuren, Vice Director of SETC, 2002. Opening address for 2002 China International Energy and Environmental Protection Exhibition \& Workshop, Beijing, November 5, 2002. 